\title{
The structural style and hydrocarbon exploration of the subthrust in the Berati Anticlinal Belt, Albania
}

\author{
Telo Velaj ${ }^{1}$
}

Received: 24 January 2014/ Accepted: 28 February 2015/Published online: 27 March 2015

(C) The Author(s) 2015. This article is published with open access at Springerlink.com

\begin{abstract}
The Albania thrust belt consists of both internal and external tectonic zones, which are westward overthrusts with large amplitude (50-100 km), above the Apulian Patform and the South Adriatic Basin. The External Albanides are subdivided into distinct tectonic-stratigraphic units: the Kruja zone (shallow carbonate water) in the east and the Ionian zone in the west, which is represented by pelagic limestone. The Ionian zone, located between the Sazan (Pre-Apuliane) and Kruja zones, consists of three anticlinal belts: the Berati, Kurveleshi and Cika anticlinal belts. Their western margin is bordered on overthrust faults, which have produced large westward overthrusts on each of them, with amplitudes of 10-30 kms, and are utilized through a large diapir masses. Therefore, they mask perspective plays in subthrusts. The Berati anticlinal belt is the most eastern in the Ionian zone and lies mostly in the Albanian territory and partly in the Greek territory. It has a length of about $225 \mathrm{kms}$ and a width $12-22 \mathrm{kms}$, and is differentiated into two sectors: the southern sector (south of the Qafa Kicoku) and the northern sector (north of the Qafa Kicoku). Understanding the evolution of evaporite tectonics is important in determining the principal features of the structural model on the Berati anticlinal belt. The changes in the lithostatic pressure on the space have a greater role in the development of evaporite tectonics, which are conditioned by the deposition thickness of the cover sediments above the evaporites and the presence of weak tectonic loops. These loops belong to the intersecting places of transverse and longitudinal fault generated since
\end{abstract}

Telo Velaj

telovelaj@verizon.net

1575 W. Street Road \# 336, Warminster, PA 18974, USA the rifting phase (T3-Cr1). Such intersecting places are the Dumrea (Albania) and Zavrohon (Greece) on the surface. We stress that evaporites are also extended over regional thrust faults of the Berati belt, helping its overthrusting westward about 20-30 km (depicted by seismic and deep wells data). The tectonic evaporite effect differs from the expansion of the Berat thrust belt. Thus, in its southern part, as a result of a diapirism that has not emerged on the surface, it is helping orogenies in developing large fan-type anticline structures (Golika, Nemercka, Mitsikeli anticlines, etc.), that have backthrusts in their eastern flank. Moreover, we encountered the presence of a carbonate massive in the middle of the EpiroAkarnani syncline (e.g. Timfeu massive in Greece), caused by the "blind" evaporite body effect. The northern sector (north of Qafa e Kicoku), is characterized by a smaller evaporite effect, which is reflected in increasing density of the anticlinal structures on the surface units and their normal passing to each other. The Dumrea diapir is a considerable ellipsoid-shape evaporite mass outcropping with a surface area of about $210 \mathrm{~km}^{2}$ and axes $20 \times 10 \mathrm{~km}$. It is an ordinary diapir with a westward overthrust $(20-30 \mathrm{~km})$. Most oil fields in Albania are in carbonate sections $(\mathrm{Cr} 2-\mathrm{Pg} 2)$ in the anticline structures delivered to the thrust of adjacent units. There is another new prospect of the high perspective: The carbonate structures under overthrust of different units (subthrust complex) of the Ionian zone. The subthrust in the Ionian zone is divided into three types: 1 . The subthrust beneath overthrust of thrust belts. These overthrusts are related to the evaporite detachment horizon, and they mask folded structures of subthrust. 2. The subthrusts beneath the overthrusts of the anticline units. These overthrusts have a local character and they are more developed in the Kurveleshi thrust belt. 3. The subthrusts beneath the 
overthrusts of the tectonic zones of the orogenetic front (Ionian and Kruja Zones) above the western autochthonous (Apulian Platform and South Adriatic Basin). These structures display duplex and triplex style. Currently, the more interesting opportunity lies in the subthrust beneath the Berati thrust belt. This has a higher perspective than the other subthrusts beneath the Kurvelesh and Cika anticlinal belts. Actually, the Berati subthrust is in the processes of being the subject of a seismic survey and exploration drilling. The discovery of a new oil field in the subthrust of the Berati anticlinal belt, with drilling of the Shpiragu-2 well, which in the first test gave 800-1300 barrels (light oil with density $35-37^{\circ}$ API) and 2-5 mmcfd gas per day, is of great importance for the entire tectonic ensemble of the Dinaric-Albanid-Hellenic. The presence of prospective structures such as the Dumrea anticline in the north and its continuation southward (the Shpiragu oil field, Molishti anticline, etc.), beneath the thrust belt, as shown by both drilling and seismic data, together with the presence of the surface structures (e.g. the Kasidhiaris, Kurenton and Thesprotikon anticlines) in Greece, shows the regional scale potential of petroleum plays. These prospects for new oil and gas discoveries constitute the object of this important paper, offering completely new ideas.

Keywords Berati thrust belt - Evaporites - Overthrust belt - Albania · Apulian Platform · Ionian Zone · South · Adriatic Basin

\section{Introduction}

Albania is part of the Dinaric-Albanid-Hellenic arc of the Alpine orogeny. It is located between the Dinarides in the north and the Hellenides in the south. The collision of the African and Eurasian plates caused the Albanides to become folded and displaced from east to the west (Fig. 1). A conventional foreland-thrust system characterizes the presentday architecture of the Albanian thrust belt (Velaj 2011).

The Apulian Platform is overthrust in the east by Albanides-Dinarides-Hellenides and to the west of Apennines (Fig. 1). The Albanides-Dinarides-Hellenides comprises four main units: the autochthonous foreland, the foredeep, the internal and the external tectonic zones. All the tectonic zones are thrusting westwards (Fig. 1), partially covering each other, and are thrust together over the autochthonous foreland (the Apulia Platform, the Peri-Adriatic Depression and the South Adriatic Basin) (Argnan 2010; Velaj 2011).

The Apennines are overthrust towards the east above the Apulian Platform. Here, subthrust plays include oil fields such as Monte Alpi, Tempa Rossa, etc. (Heard and Robinson 2010). Overthrusting occurred during the Neogene and Quaternary Periods (Scrooca 2010; Cazzola et al. 2011).

The autochthonous foreland is represented by the Apulian Platform (Italy), Sazani zone (Albania) and Paxos zone (Greece). The Apulian Platform is not folded, but the Sazani and Paxos zones are folded, offering greater prospects for oil and gas exploration (Velaj 2011). These subthrusts plays, beneath the Albanides-Dinarides-Hellenides orogenic units, are analogous to those in Italy (Fig. 1) (Picha 2002; Heard and Robinson 2010).

The Peri-Adriatic Depression represents the basin of the external zones of the Albanides-Dinarides-Hellenides and the Apennines in Italy. Post-carbonate deposition is composed of terrigenous sediments $\left(\mathrm{N}_{1}^{3 \mathrm{t}}-\mathrm{N}_{2}^{\mathrm{P}}\right)$, the placement and distribution of which definitely indicate a basin environment, which itself is included in the South Adriatic Basin (Fig. 2) (Zappaterra 1994; Picha 2002). The southern and western part of this basin (Albania, Greece and Italy) overlies the Ionian, Kruja and Apulian Platform (Frasheri et al. 2009; Bega 2010; Velaj 2012), whereas in the north, it continues with the South Adriatic Basin, which has
Fig. 1 Schematic geological cross-section between the Albanides and Apennines, see Fig. 2 for location (According to Cazzola et al. 2011, modified by Velaj)

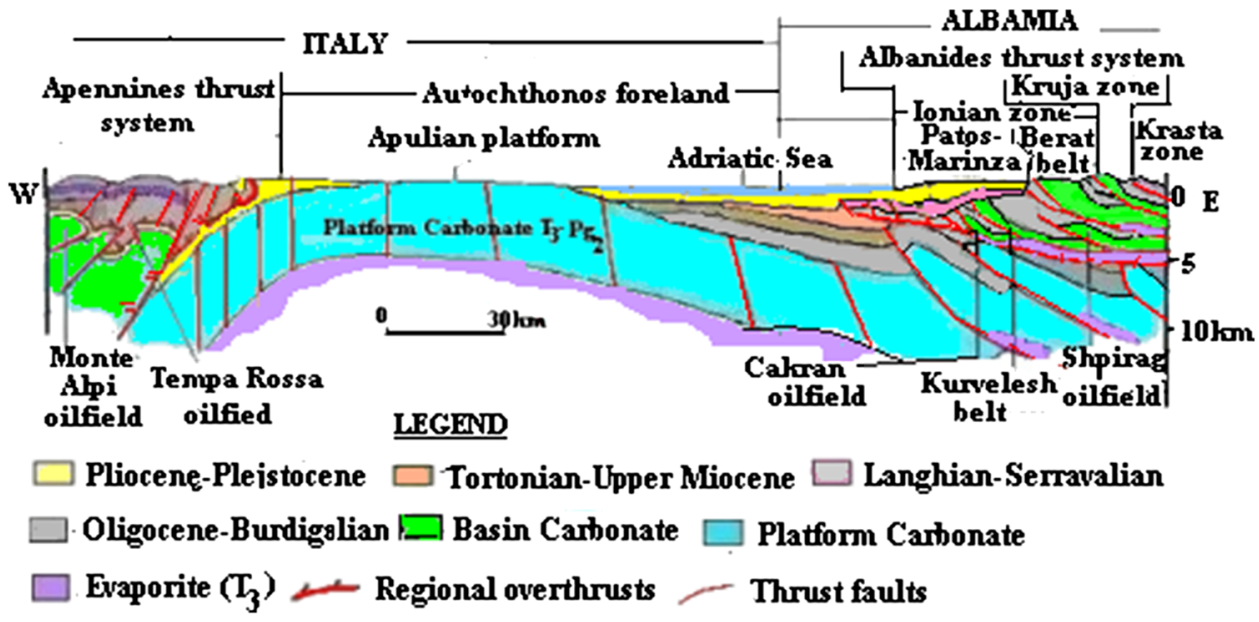


Fig. 2 The tectonic scheme for the relationship between Albanides-DinaridesHellenides-Apeninnes (According to Zappaterra 1994, modified from Velaj)

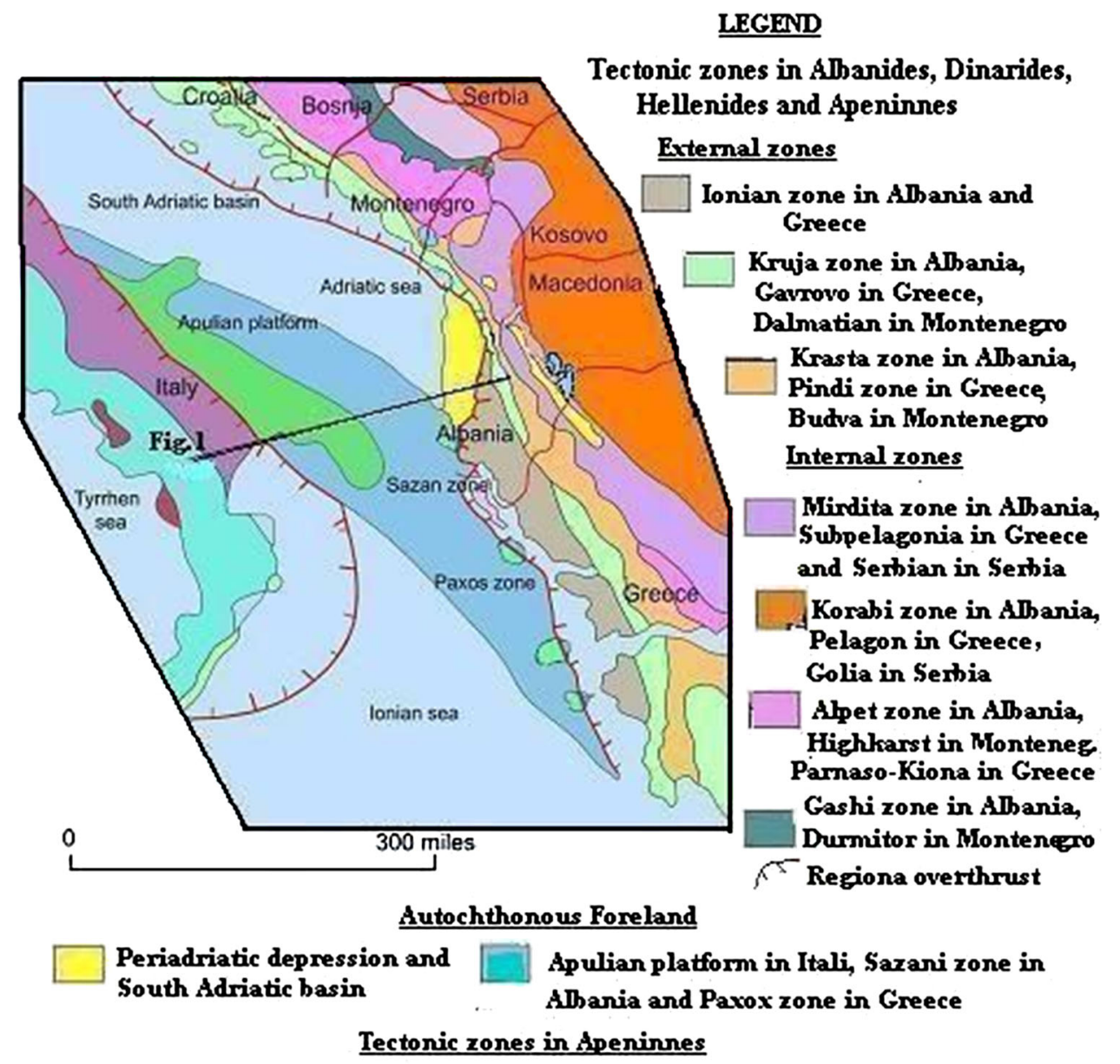

Apeninnes thrust and fold belt system continuous sedimentation from the upper Triassic to the Pliocene.

\section{General information on the albanides}

\section{Regional geology}

In Albania, the thrust belt is divided into two parts: the Internal and the External Albanides. The Internal Albanides composed of the Mirdita and Korabi zones, which are characterized by the presence of allochthonous ophiolites (Upper Jurassic) and by many folding phases (Upper Jurassic, Eocene etc.) (Fig. 1). The external Albanides (a carbonate thrust belt), are composed of the Ionian, Kruja and Krasta-Cukali zones (Fig. 3).

Only the external zones and the autochthonous foreland have been explored for the petroleum industry. Geological and geophysical studies performed in the External Albanides show that the structures and structural belt have been displaced westward by 10-30 km (Fig. 5) (Velaj 2011). The eastward amplitude of a backthrust in the eastern flank of the structures may be up to $5-10 \mathrm{kms}$ (Figs. 15, 16) Velaj (1999).

Sratigraphy of the Ionian Zone and Berati anticlinal belt

In terms of stratigraphy, the Ionian zone consists mainly of Upper Triassic evaporite $\left(\mathrm{T}_{3}\right)$, carbonates of the Upper Triassic to the Eocene $\left(\mathrm{T}_{3}-\mathrm{Pg}_{2}\right)$, flysch-flyschoides of the Oligocene to the Serravallian $\left(\mathrm{Pg}_{3}-\mathrm{N}_{1}^{2 \mathrm{~s}}\right)$ and Neogene marine sediments $\left(\mathrm{N}_{1}^{3 \mathrm{t}}-\mathrm{N}_{2}^{\mathrm{P}}\right)$ (Velaj 1999; Karakitsios 2003) (Fig. 4).

The Upper Triassic evaporites consist of gypsum, anhydrides, salts, multicolored clays and breccias with interbedded dolomite and thin organic-rich shales. Volcanic rocks (Dumre, Picar-Kardhiq), quartz bipyramidal (Dumre, Picar-Kardhiq, Delvine, Gline, Janicat, Korab) and amphibolite rocks (diabaze, gneiss and volcanic tuffs) are 
Fig. 3 Tectonic map of Albania and anticline carbonate structures in the Ionian and Kruja Zones (Modified from Velaj)

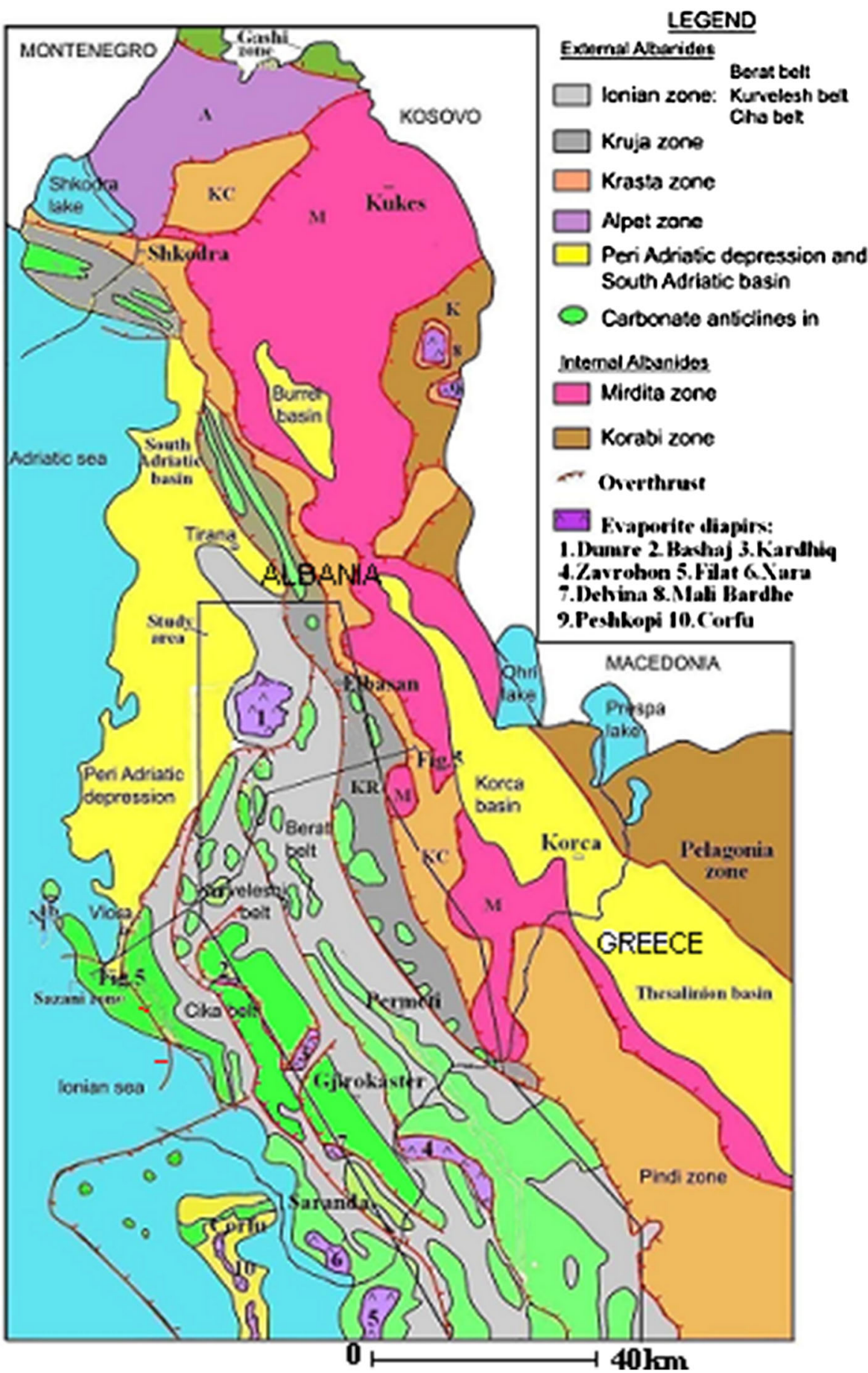

encountered locally. Salts are widespread in the Kurvelshi anticlinal belt, whereas gypsum and anhydrite facies predominates in the Berati and Cika belts (Velaj 2001).

The carbonate formation is of Upper Triassic to Eocene, and in general, it belongs to pelagic facies. Upper Triassic dolomite and massive limestones with organic-rich shale interbedded (Lower Jurassic) represented neritic facies and are overlain by pelagic limestone with chert, marl and shale interbedded, which was deposited continuously throughout the Jurassic, Cretaceous and up to the Upper Eocene. At the beginning of the Lower Jurassic (Lias), Ionian zone differentiation is noticed at the bottom of the basin, which is associated with the formation of two carbonate facies: pelagic facies represented by crystalline limestone with chert lenses and neritic facies represented by algal limestone and dolomite. In the Toarcian (J13t), the differentiation of the basin bottom of the Ionian Trough becomes clearer, having an island archipelago view. In the central 


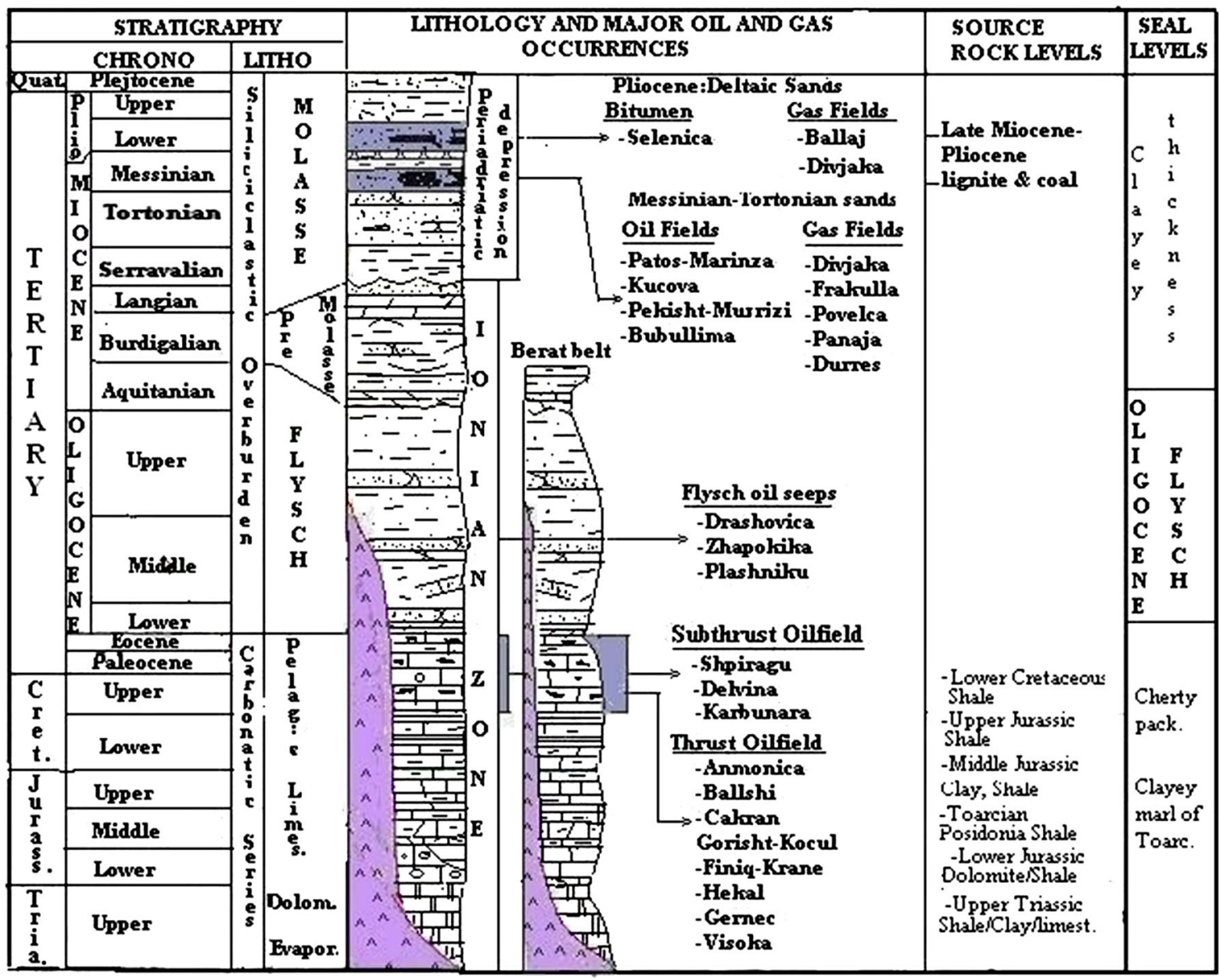

Legend

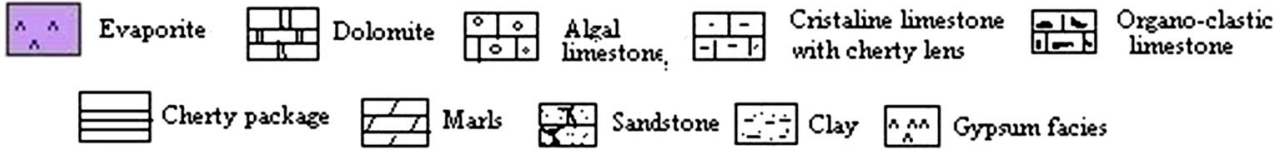

Fig. 4 Generalized stratigraphic column for the Ionian zone and the Berati anticlinal belt showing lithologies, oil fields, source rocks and seals

part of the Ionian zone (Kurveleshi anticlinal belt), lithofacies of marls schist with Possidonia is formed, whereas on both sides (Berat and Cika anticlinal belts), the lithofacies of limestone and dolomite limestones with amonities, know as "Amonitico Rosso", are formed. It is shallower than "Posidonia" facies (Velaj 2011). The Middle Jurassic is represented by the lower chert package which consists of many cherts followed by micritic and biometric limestone deposition also rich in cherts. During the Upper Jurassic, the deepening of the Ionian Trough continue and is associated with a marked increase in silicious material (the upper chert package), which meets in the entirety of the Ionian zone. At the Tithonian-Berrasian, the sea depth reaches the largest values covering the Liassic neritic deposits. These deposits are overlain unconformably on micritic-biometric limestone rich in tintinide.
In the Ionian zone, the Cretaceous depositions are of pelagic facies and are represented by porcellaneous, clayey limestone and bituminous clays (Lower Cretaceous) on which lies phosphatic-biometric limestone and the intercalation of organic-clastic and pelitomorphic limestone (Upper Cretaceous). During the Paleocene-Eocene, the pelagic conditions of Upper Cretaceous paleogeography are still preserved, reflected in the formation of micritic and detrital limestone intercalations. At this time, the erosion activity in the Upper Cretaceous carbonate platform from the Kruja zone in the east and the Sazani zone in the west, contributed as a distal source to the thick carbonate turbidities deposited in the Ionian Basin during the Upper Cretaceous and Paleocene (Velaj et al. 1999; Roure et al. 2004). These turbidities, which reworked platform carbonate, are interbedded within a finer-grained pelagic 


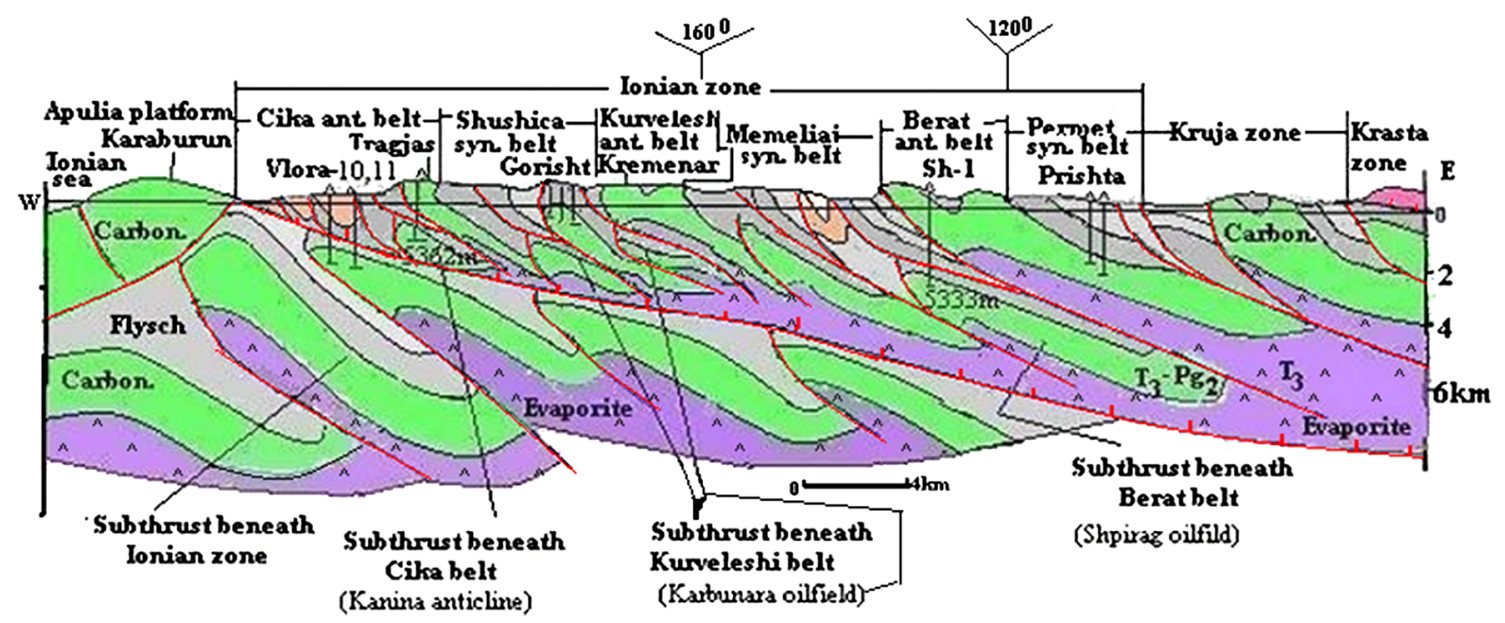

Fig. 5 Geologic cross-section through the Apulian Platform,Ionian and Kruja Zones, see Fig. 3 for location

limestone. These carbonates are highly fractured because of orogenic processes and they make up the main hydrocarbon reservoirs in the large structural closure in the thrust and subthrust. Carbonate formation thickness in the Ionian zone varies from 2100 to $2900 \mathrm{~m}$.

A transitional zone with the marls, 20-50 m thick, mark the change in sedimentation from pelagic carbonate to a flysch succession of the Oligocene age, which form the overlying seal for the carbonate reservoirs of thrust and subthrust sheets. The flysch consists of intercalation of sandstones, siltstone and clays, as well as pudding stones and limestones olistoliths of the Upper CretaceousEocene age. Its thickness varies from 1000 to $3000 \mathrm{~m}$, which reduces from the east (Berati anticlinal belt) to the west (Cika anticlinal belt).The eastern part of the Ionian zone (Berati anticlinal belt) emerged from the end of Upper Oligocene, because the coastal line (Berati anticlinal belt), continues its regression westward. From the Oligocene to the Aquitanian, the sea regression is intensified, and at the end of Aquitanian, the western sector of the Ionian zone (Kurveleshi and Cika anticlinal belts) is tectonized and emerged. The tops of the anticlinal structures are eroded. The sedimentation continues without interruption in the synclines.

The premolasses formation consists of marls, marl clays, sandstones and lithothamnic organogenic limestone. It belongs to the Aquitanian-Burdigaliane-Lower Serravallian period, and it meets only in the Kurveleshi and Cika anticlinal belt (Fig. 4). The thickness of this formation varies from $900 \mathrm{~m}$ in the east (Kurveleshi anticlinal belt) and up to $2300-2500 \mathrm{~m}$ in the west (Cika anticlinal belt).

The molasses formations of the Middle Serravallian to Pliocene age are composed of a large number of sandyclayey mega sequences (going upwards). In some cases, these mega sequences become more complete and beginning with conglomerates and clastic limestones with lithothamnion and ending with coals or clayey-gypsum. They are wide-spread in the Peri-Adriatic Depression and South Adriatic Basin. In the eastern board, these depositions are placed transgressively in the Ionian and Kruja zones, in the northeastern part of Albania. Conversely, in the west and southwest, the section is successive with thicknesses of about 7000-8000 m (Zappaterra 1994; Velaj 2012). A a result of the sedimentation conditions changing in the Messinian, the clayey-sandy lithofacies was formed in the eastern part of the Peri-Adriatic Depression, and the clayey-gypsum lithofacies was formed in the western part.

The Upper Miocene molasses deposits lie transgresively over the eroded part of the carbonate of the Kucova and Patos-Verbas anticlinal structures. It is known that a great quantity of oil and gas reserves has migrated from the eroded carbonate to the sandstone reservoirs of these deposits, and has saturated them, up to outcrop on the surface, in the south of Patos and in the east of Kucova. During the geological period from the Upper Miocene to the Quaternary, at the parts where these deposits come out to the surface, the oil is oxidized, and the light fraction move, and are turned into bitumen, and this has served as a screen (seal) to prevent further of migration.

A common feature of the Ionian zone is that during the molasses cycles their structures and the structural belts (Berati, Kurveleshi and Cika anticlinal belts) have increased the thrusting and backthrusting degree as a result of a powerful tectonic development. Their thrusting westward and backward, is a process assisted by the presence of Upper Triassic evaporites beneath the thick carbonate $\left(\mathrm{T}_{3}-\right.$ $\mathrm{Pg}_{2}$ ), represented by the thrust belts and thrustsheets (Velaj 2011). The local evaporites are exposed to the surface, because of regional and local faulting (e.g., the Dumrea and Zavrohon diapirs) (Fig. 3). 
Therefore, the most general model of duplex structures of the Ionian zone is as follows: carbonate structure on the surface, fault plane, flysch and subthrust underlying the carbonate structure on subthrust (Delvina, Shpiragu oil field, etc.) (Figs. 6, 10, 16, 17, 18, etc.). The subthrust complex may have considerable petroleum potential.

\section{Oil and gas exploration}

Geological and geophysical studies show that in the western edge of the thrust belts of the Ionian zone, a narrow strip of flysch deposits is present which originated from the subthrust complex, that creates folds associated with the thrusting faults, exposed as rootless folding (Figs. 10, 16, 18, etc.). Their roots represent perspective structures of the subthrust underlying the thrust belts (Figs. 10, 16, etc.). However, this flysch has generally lost its relationship with its eastern carbonate roots (Figs. 10, 16, 18, etc.) Velaj (1999).

There are two types of oil and gas accumulation in Albania:

First, oil and gas accumulation in the carbonate of the Upper Cretaceous-Eocene age are associated with folded and faulted anticlines, which provide good structural traps, charged from Mesozoic source rocks (Table 1) (Gorishti, Ballshi, Karbunara, Visoka, Hekali, Amonica and Delvina) (Fig. 9). There are two main types of carbonate plays: (1) heavy oil reservoirs charged during the Serravallian (Gorishti, Amonica, Ballshi, Visoka, Karbunara, Gerneci, etc.) and (2) light oil and condensate charged during the postPliocene (Delvina, Cakran, Shpiragu, etc.) (Curri 1993; Prifti and Muska 2010). Most of them belong to the thrust complex of the Ionian zone (Kurveleshi anticlinal belt) and only three belong to the subthrust (Delvina, Karbunara, Shpiragu). The Delvina oil field is completely covered with the overthrust of the Mali Gjere anticline. Its prognosis, exploration and discovery are performed based on indirect geological data Velaj (1999). The Karbunara oil field located beneath the overthrust of the Kremenara anticline (Fig. 5), is considered as a typical oil field formed into a zone with an intensive development tectonic. Shpiragu is a ramp anticline in the Cretaceous-Eocene beneath the overthrusting of the Berati anticlinal belt (Fig. 5) (AKBN 2012).

Second, oil accumulation in the clastic plays is composed of Tortonian-Messinian reservoirs sand pinch-out and sand lenses sealed by inter-formational shales. There are two main types of clastic plays: the first being those of Miocene sandstones charged from underlying Mesozoic

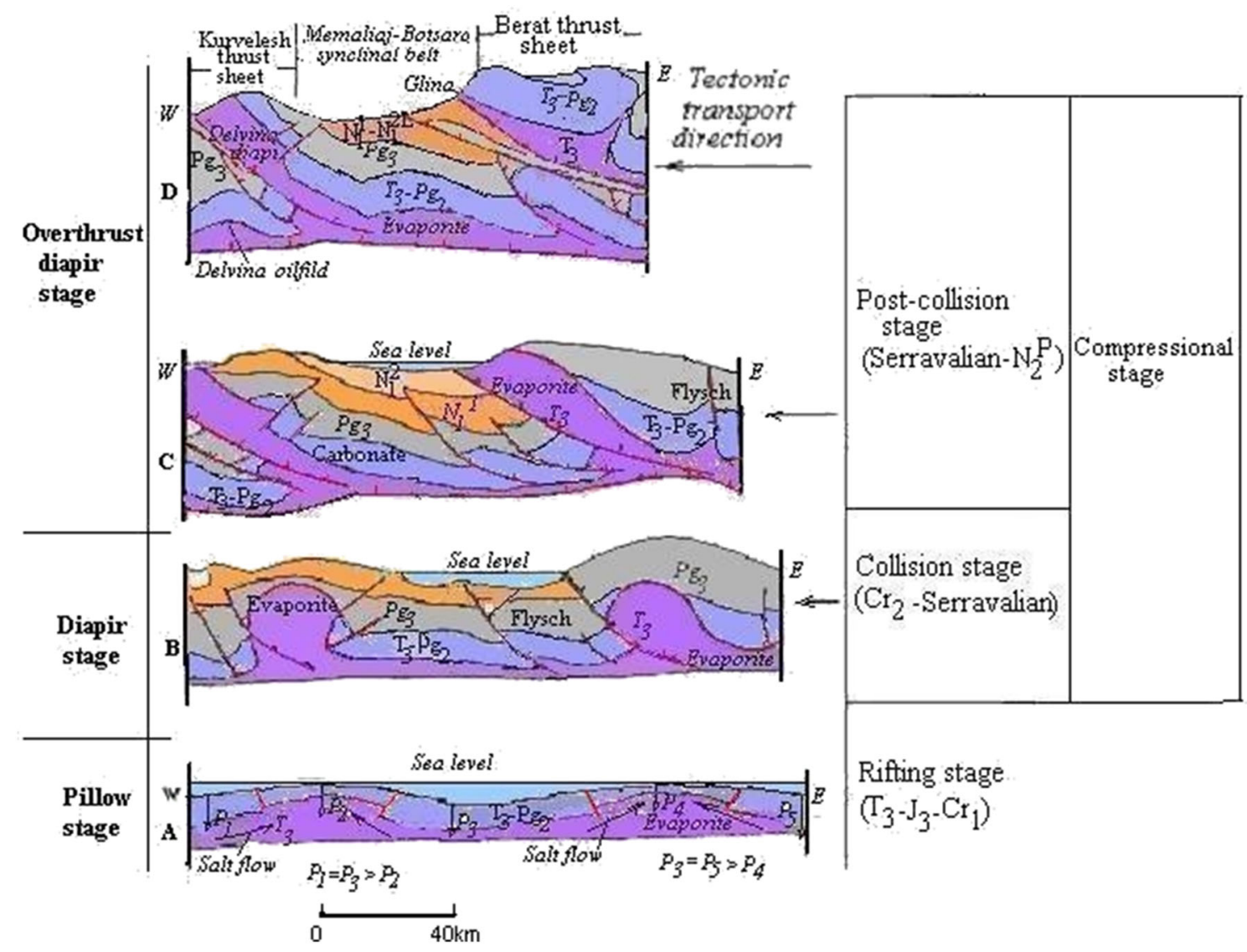

Fig. 6 Geological development scheme in the Berati anticlinal belt 
Fig. 7 The schematic profile of thickness change from the north to the south in the Berati anticlinal belt, see Fig. 9 for location

Fig. 8 Schematic profile of thickness change from the east to west in the Berati anticlinal belt, see Fig. 9 for location
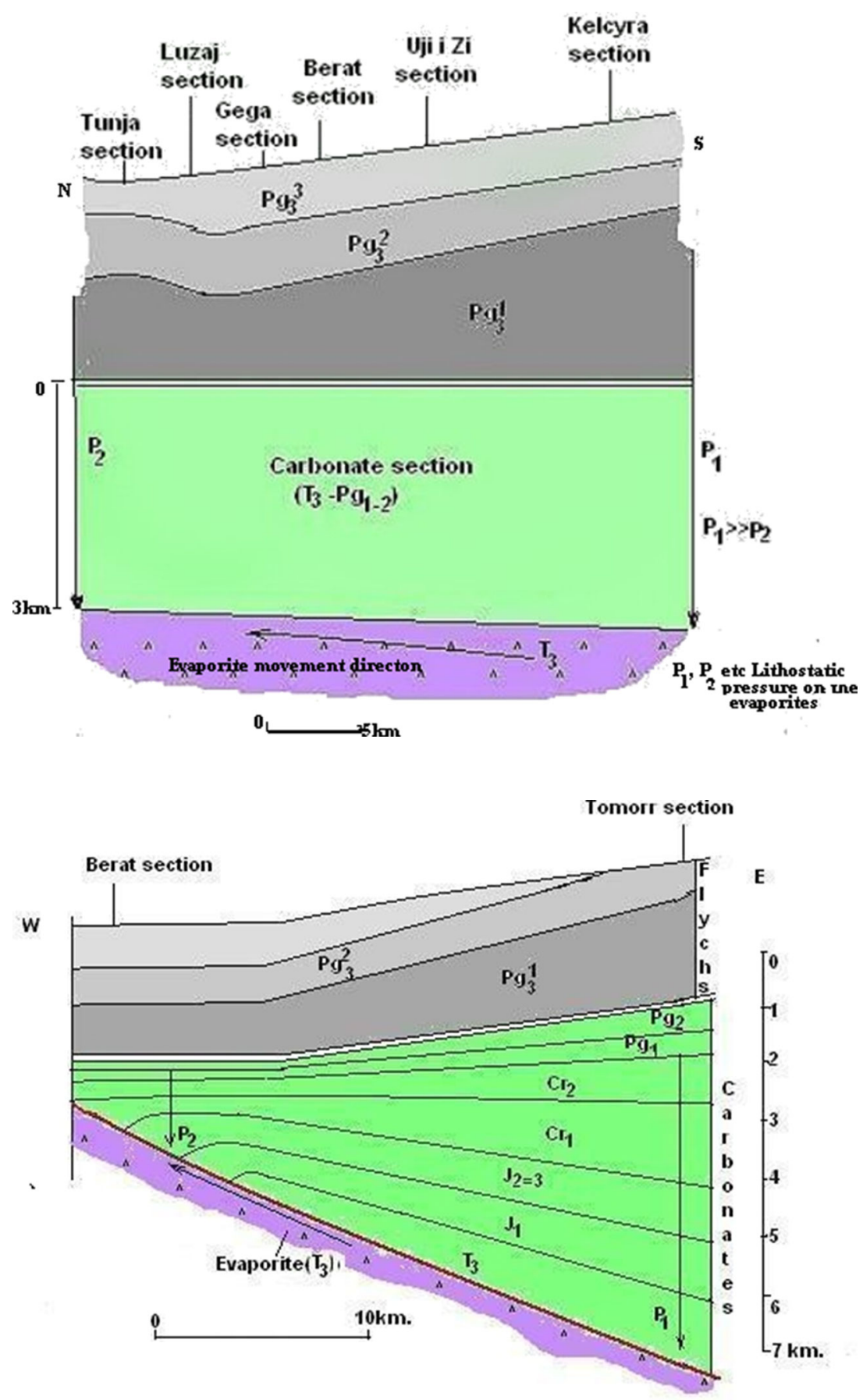

deep-water carbonate structures (Patos-Marinza and $\mathrm{Ku}$ cova oil field). The organic matter present in these depositions and the condition and history of the geologic development, have been not favorable for hydrocarbon formation. This means that the oil here is accumulated through the vertical migration from the carbonate structures (Kucova anticline etc.) (Fig. 19). Their oil and gas bearings are mainly related to lithological, lithologicalstructural, bedded, tectonically screened, and irregular reservoirs (Prifti and Muska 2010). The Patos-Marinza is the largest producing oil field in continental Europe, holding approximately 7.5 billion barrels. The Kucova oil field has 297 million barrels of original oil in place. The reservoirs are Tortonian and Messinian sandstones that overlie the carbonate thrust anticline (Patos-Verbas and Kucova) (Fig. 19). The second type of clastic plays is biogenic gas accumulation in Miocene and Pliocene sandstones charged by the terrigenous source rock of the 
Table 1 Source rocks in the Ionian zone

\begin{tabular}{|c|c|c|c|c|c|c|c|c|c|}
\hline No. & Zone & Age & Lithology & Sample location & TOC (\%) & HI (MgrHc/gr) & $T_{\mathrm{m}}$ & Kerog. type & $\mathrm{VR} / E$ \\
\hline 1 & Ionian & Upper Triassic & Shale/clay/limestones & Outcrop & $0.02-38.5$ & 617 & 416 & I & $0.54-0.88$ \\
\hline 2 & & Lower Jurassic & Dolonute shale & Outcrop & $0.01-52$ & 450 & 434 & $\mathrm{I} / \mathrm{II}$ & $0.55-0.75$ \\
\hline 3 & & Toarcian & Posidonia shale & Outcrop & $0.09-3.7$ & 588 & 432 & I/II & $0.5-0.6$ \\
\hline 4 & & Middle & Clay & Well & 2 & 505 & 424 & II & 0.57 \\
\hline 5 & & Jurassic & Shale & Outcrop & $0.04-9.4$ & 508 & 432 & I & 0.52 \\
\hline 6 & & Upper Jurassic & Shale & Outcrop & $0.03-509$ & 520 & 430 & I & $0.45-0.57$ \\
\hline 7 & & Lower Cretaceous & Dolom/shale & Outc./well & $0.02-27$ & $521-700$ & 413 & I/II & $0.45-0.54$ \\
\hline
\end{tabular}

Peri-Adriatic Depression (Divjaka, Panaja, Frakulla, Povelca, Ballaj and Durresi) (Fig. 9).

\section{History of exploration}

To date, exploration and production in Albania have focused primarily on shallow carbonate formations (1500-3500 m) that produce oil and gas condensate in thrust structures: Visoka, Gorisht-Kocul, Ballsh-Hekal, Cakran-Mollaj and Finiq-Krane. All these oil fields belong to the Kurveleshi anticlinal belt, which is the most complicated part of the Ionian zone. The Balkan region has proven oil reserves totaling about 345 million barrels. Of that, 198 million barrels are located in Albania (AKBN 2012).

Intensive exploration efforts during 1989 yielded a new Delvina oil field (condensate and gas).This was the first oil field discovery in the subthrust (Fig. 5) (Velaj et al. 1998). The current production from the two existing wells on this oil field (Del-4, Del-12) is $700 \mathrm{Mcf} / \mathrm{ds}$ of natural gas and 47 barrels/day of 62.5 API condensate. At roughly the same time, the Karbunara oil field was discovered beneath the Kremenara anticline (Fig. 5). The Kanina-1 drilled $(5362 \mathrm{~m})$ in the Tragjasi anticline (Cika anticlinal belt), was located beneath an anticlinal structure in the subthrust (Fig. 5) and it has proven hydrocarbons in the system: a $163 \mathrm{~m}$ oil leg was found, but not flows (16-20 API, low porosity $0.019 \%$ ). The wells Vlora-10 and Vlora-11 have attacked one anticlinal structure on the subthrust, beneath the overthrust of the Ionian zone (Fig. 5), and a small amount of oil and gas flowed on the surface Velaj (1999; Velaj 2001). In December of 2001, the Occidental Company (OXY) declared the Shpiragu discovery, after drilling and testing of the Shpiragu-1 well in the subthrust, beneath the overthrust of the Berati anticlinal belt (Figs. 5, 20). The Shpiragu well proved light oil (370 API) from a fractured carbonate reservoir of the Upper Cretaceous-Eocene. The available data (deep wells Dumre-7, Shpiragu-1, Shpiragu2 , etc., and seismic works), show that the Shpiragu anticlinal structure extends to the north beneath the overthrust of the Dumre diapir (Fig. 10) and to the south with the
Molishti and other similar structures, etc. (Fig. 20). There has been limited exploration to date. However, three-dimensional technology and deep wells drilling have created the possibilities for intensive exploration of the subthrust of the Berati thrust belt, which is with high perspective. The Shpiragu-2 well reached a total depth of $5547 \mathrm{~m}$ in late June (2013), and the company has completed setting the production line. The rig has been released and it will be mobilized to the Molisht- 1 drill site upon completion of the road and lease construction, where the depth of the top carbonate reservoir is estimated to be roughly 4500-4600 m. Stimulation and testing equipment rig up will begin once the drilling rig is off the Shpirag-2 lease. The company intends to test $350-400 \mathrm{~m}$ of the target carbonate zone. Two other drilling sites are also currently along the Shpiragu thrust sheet (Petromanas Energy Inc 2013).

The content of this paper is based on the latest data obtained from deep wells (Shpiragu-1, Shpiragu-2, Dumre7, Kanina-1. Delvine-4, Ardenica, etc.), a considerable volume of high quality 2D seismic data, and various complex studies (geochemical, stratigraphic, tectonics, etc.). The aim is to shed light on the prospects of oil and gas exploration in the subthrust of the Berati anticlinal belt, and in the subthrust of all the External Albanides. The conclusions of the article also apply to exploration in the upthrust of the External Hellenides (Greece) and Montenegro.

\section{Petroleum system}

The thrusting and overthrust model in the External Albanides (Ionian and Kruja Zones), was proved from geological surface observation Velaj (1999, 2001; Meco and Aliaj 2000; Karakitsios 2007), and seismic works and deep wells (Shpiragu-1, Shpiragu-2, Dumre-7, Kanina-1, Ardenica-7, Vlora-10, Vlora-11, etc.). From these data, it seems that Albania has good potential for further hydrocarbon exploration. The prospect of Albania is associated 
Fig. 9 The schematic map of distribution of oil fields, regional faults in the External Albanides and lithological sections

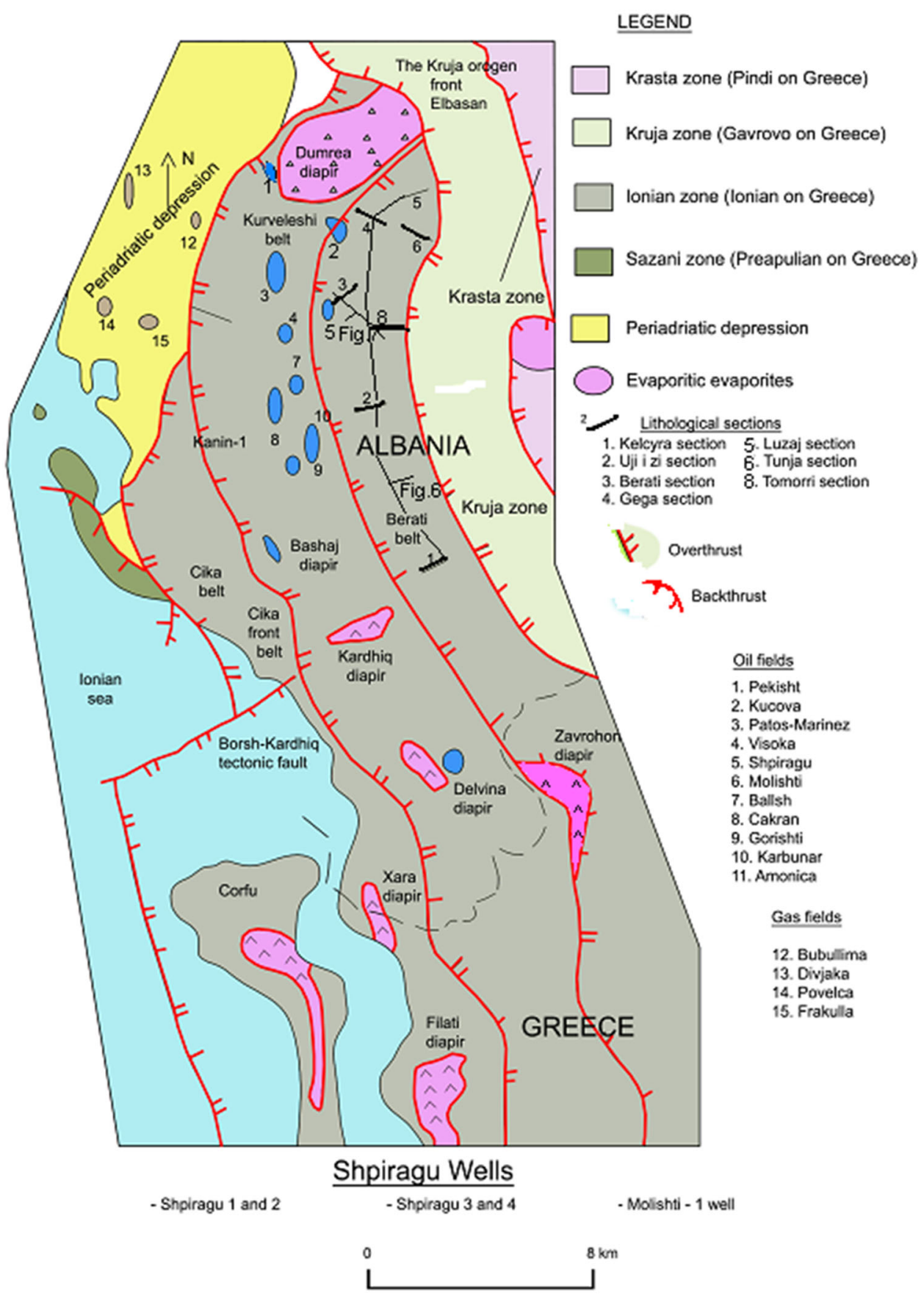

with folded and hanging wall anticlines formed by highangle faults, which provides good structural traps, sourced by Mesozoic source rocks (Velaj 2011; Zelilidis et al. 2003) (Table 1). The focus in recent years has been on deeper subthrust carbonate structures that contain the lighter oil and condensate (Petromanas Energy Inc. 2013). Potential discoveries will be found in subthrust complexes, under the overthrusts of the structural anticlinal belts (Berati, Kurveleshi and Cika anticlinal belts) and under the overthrusts of anticline units (Kurveleshi anticlinal belt)
(Fig. 5). In addition, good hydrocarbon potential will be found under the regional overthrust of tectonic zones of orogenetic fronts (Ionian and Kruja Zones), above the western Albanian autochthonous (Apulia Platform and South Adriatic Basin). This overthrust has a regional character (Albania, Greece and Montenegro) and has masked the subthrust structures with its large dimensions (Fig. 5) and high perspective. One of these structures is attacked by an exploratory well in the Vlora region (Vlora10, Vlora-11) (Fig. 5) (Velaj 2011). 
Fig. 10 Schematic geological cross-section in the Dumrea area

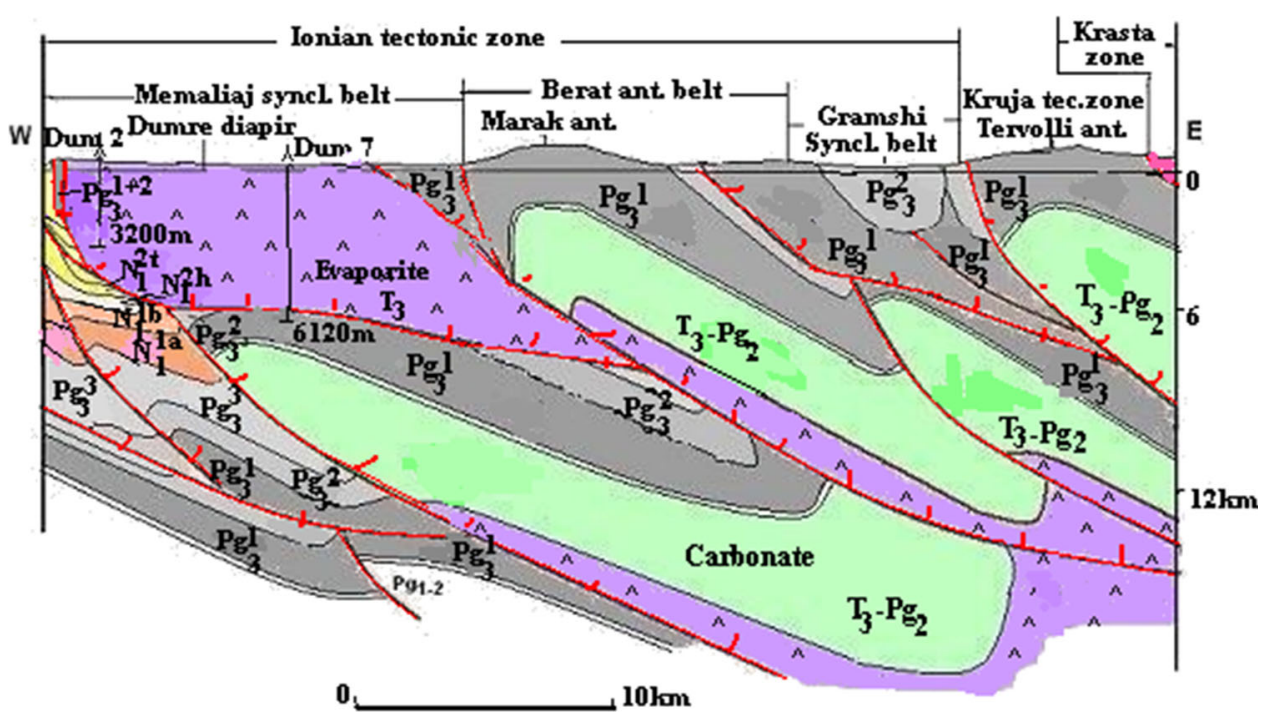

Fig. 11 Seismic cross-section through the Dumre diapir, see Fig. 14 for location

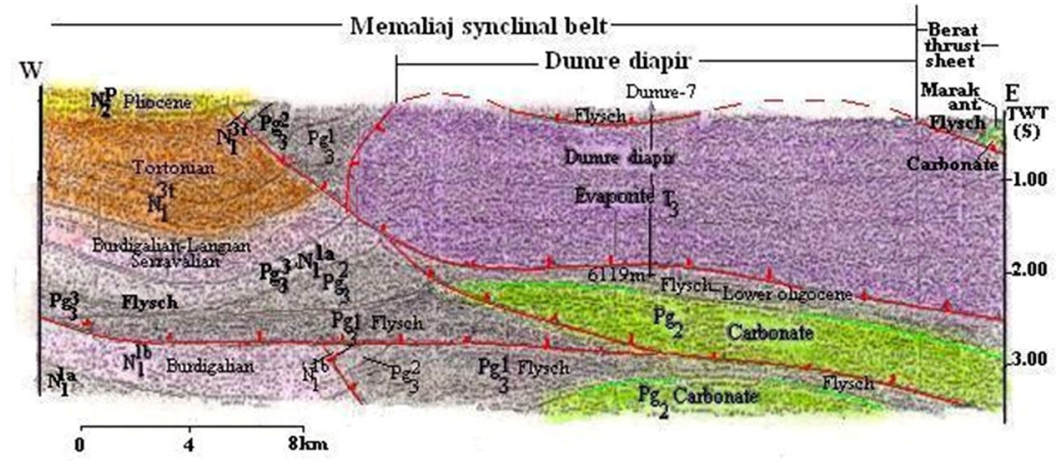

\section{Reservoir rocks}

Oil and gas reservoirs have been proven in both the deeper marine carbonates of the Ionian zone and in the clastic section of the Peri-Adriatic Depression. The limestone reservoir ranges in age from the Upper Cretaceous to the Eocene. The main type of reservoir consists of fractured carbonates. The reservoir storage capacity, from the Eocene to the Upper Cretaceous is greatly improved, because of increases in secondary porosity, which consists of fracture and vuggy porosity, and some levels have good porosity up to $8 \%$. Core data on the Cakran oil field show matrix porosity ranging from 2.5 to $3 \%$ with a maximum porosity of $6 \%$ including fractures. From the well core measurement of Paleocene reservoirs belonging to the Kurveleshi anticlinal belt, the fracture porosity was found to range between 2.4 and $2.5 \%$ (Prifti and Muska 2010).

The reservoir of the central part of Albania, related to Miocene deltaic sandstones, has a porosity ranging between 10 and $30 \%$ and permeability ranging between 2000
Fig. 12 Schematic geological cross-section in Zavrohon diapir, see Fig. 14 for location

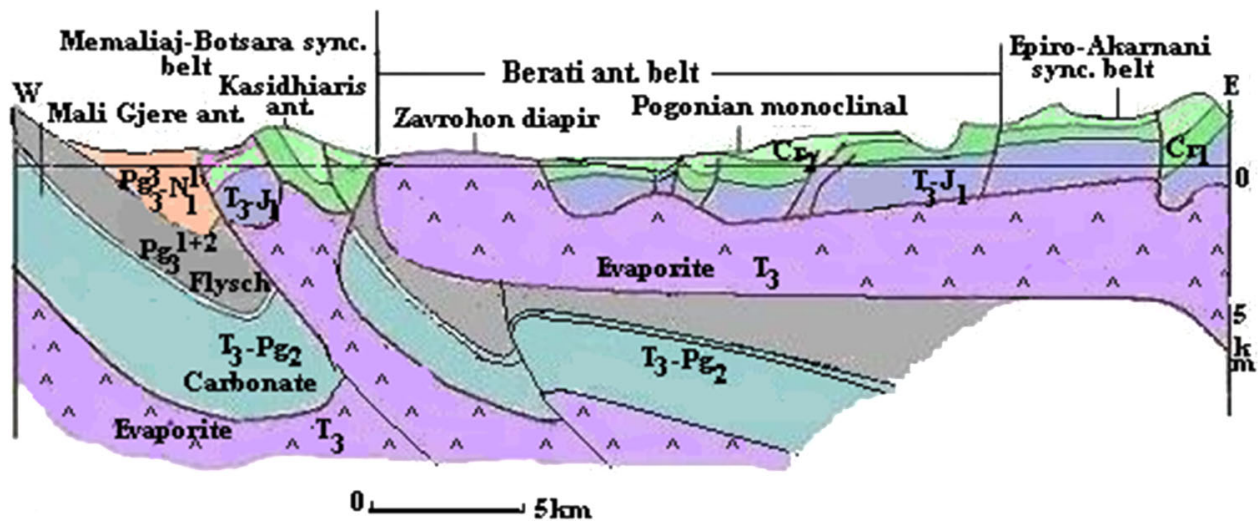

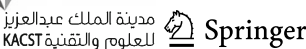


Fig. 13 The change of the structural plane of the Berati anticlinal belt over time and its evaporite tectonics
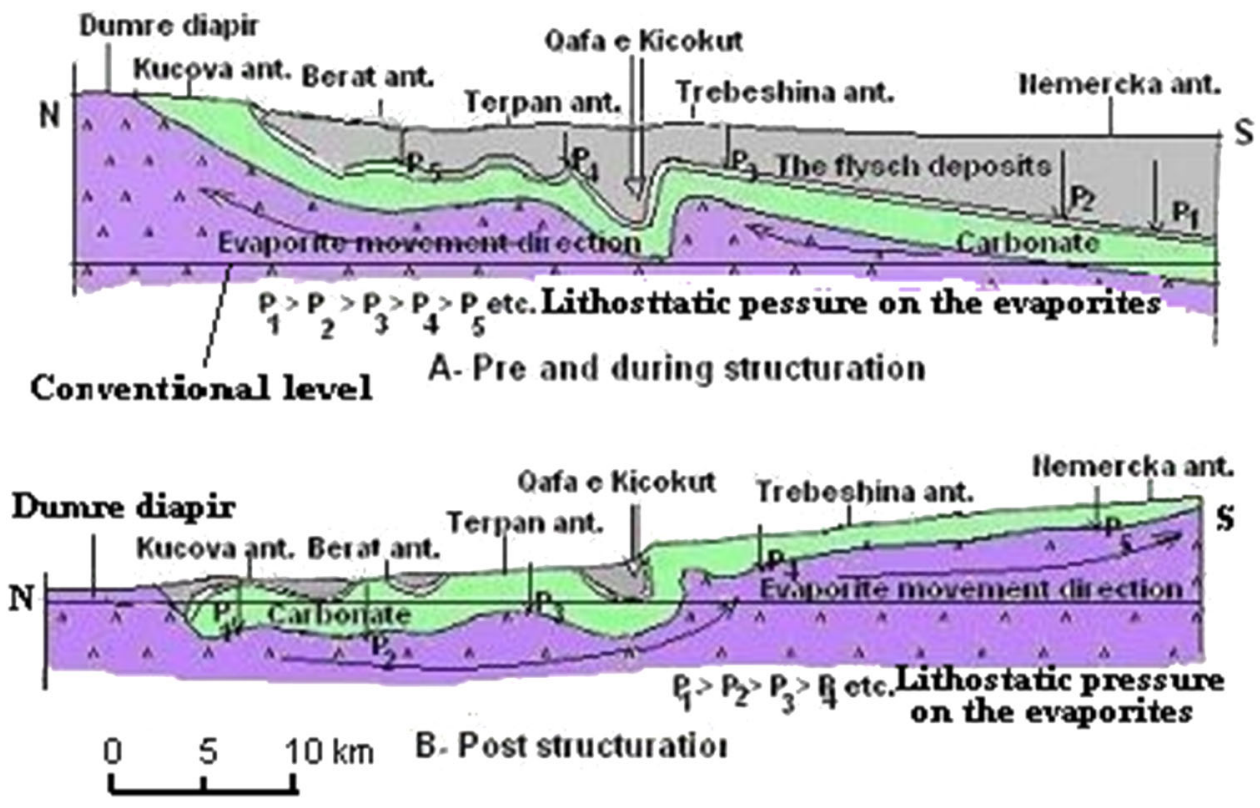

and 300 md, similar to the Patos-Marinza and Kucova oil fields.

The reservoir of the gas fields of the Peri-Adriatic Depression, related to molasses sandstones of the late Miocene (Tortonian-Messinian) or turbidities of the Pliocene age, has a porosity ranging between 12 and $37 \%$.

\section{Seals}

Flycsh and flycshoidal deposits of the Oligocene age $\left(\mathrm{Pg}_{3}\right)$ have proven to be effective seals for hydrocarbon accumulations in carbonate sections including the Gorisht-Koculi, Cakran, Balsh-Hekal and Amonica oil fields. In addition, analogue flysch are effective seals for carbonate subthrust reservoirs (Shpiragu, Delvina, Karbu-nara oil fields) and it will be effective for all the subthrusts in the Ionian zone. The considerable clayey thickness of the Tortonian-Pliocene has been proved as a good seal for the gas fields (Divjaka, Kryevidhi, Frakulla, Povelca, Ballaj etc.) and oil fields (Patos-Marinza, Kucova and PekishtMurrizi), in the Peri-Adriatic Depression (Fig. 4).

The following are also predicted to be good seals within the carbonate formation of the Ionian zone::clayey-marl of the Toarcian $\left(\mathrm{J}_{1}^{3 \mathrm{t}}\right)$, cherty packages of the Jurassic and clayey thin layer of the Lower Cretaceous.

\section{Source rocks}

Several source rock levels have been observed in outcrops in the Ionian zone with good to excellent quality. Source rocks of the Upper Triassic-Lower Jurassic prove to have total organic carbon (TOC) value of 4.96-29.6\%. Based on the values of the Hydrocarbon Index $\mathrm{HI}=617-778$
$\mathrm{mgCH} / \mathrm{gr}$ and the maceral components, the organic matter is Type I, able to generate liquid hydrocarbon. The vitrinite reflectance $\left(R_{\mathrm{o}}=0.65-0.70 \%\right)$ shows that the organic matter is matured. Moreover, black shale intercalations of the Upper Triassic from thin to thick organic-rich layers, comparable to those of the Burano formation (Lower Triassic) in Southern Italy (Scrooca 2010), with higher TOC values (up $52 \%$ ), have been recorded. In addition, in the Toarcian limestone $\left(\mathrm{J}_{1}^{3 \mathrm{t}}\right)$ met one organic-rich level corresponding to widespread Posidonia shale, with a TOC of 2-20\% and Type I and II organic matter. The TOC for the source rock of the Jurassic is $0.17-15.66 \%$. The maceral components of the organic matter show that it belongs to Type I-II, able to generate liquid and gaseous hydrocarbons. The vitrinite reflectance values $R_{\mathrm{O}}>0.5$ show that the organic matter is matured.

Very good source rock is found in the Lower Cretaceous of the Berati anticlinal belt, with TOC $=0.34-26.1 \%$ and $\mathrm{HI}=272-666 \mathrm{mgHc} / \mathrm{gr}$, (belonging to Type I/II, able to generate liquid hydrocarbon). The vitrinite reflectance values $R_{\mathrm{O}}=0.42-0.53 \%$ show that the organic matter is in the maturing stage or is matured. A couple of thicker shale/limestone intervals are known from the Lower Cretaceous with maximum TOC of $27 \%$ (Prifti and Muska 2010) (Table 1).

The flysch and flyschoidal deposits of the Ionian zone, based on the maceral component (where the oxidized and wooden components predominate), as well as the average value of $\mathrm{HI}=71 \mathrm{mgHc} / \mathrm{gr}$, show that their organic matter is able to generate gaseous hydrocarbons.

The geochemical indexes of the organic matter from the Tortonian deposits in the Peri-Adriatic Depression: $\mathrm{HI}=34.8 \mathrm{mgHc} / \mathrm{gr}, \quad R_{\mathrm{o}}=0.330 \%$ as well as the 
predominating oxidized and wooden composition, show that the organic matter of these deposits is able to generate gas of biogenic and mixed origins.

In some cases, a higher content of liptinites of continental origins is noticed in the organic matter of these deposits, which is able to generate unsaturated liquid hydrocarbon condensate.

Differences are noticed between the geochemical indexes of the Pliocene in the Peri-Adriatic Depression and those of Tortonian (i.e., an increase in the "oxidized" composition and the decrease of the liptinite composition). The organic matter of the Pliocene deposits was able to generate dry methane gas of biogenic origin.

\section{Trap formation and migration}

Three main periods of massive migration and accumulation of oil are distinguished. These periods coincide with three main phases in the formation of structures of the Ionian Basin: The Berati anticlinal belt underwent a compression regime during the Upper Oligocene-Aquitanian, whereas the Kurveleshi and Cika anticlinal belts were thrust-folded at the end of the Lower Miocene and Pliocene. These main folding phases are responsible for the formation of the carbonate traps $(\mathrm{Cr} 2-\mathrm{Pg} 2)$, for oil and gas accumulation. The trap-formation mechanism in the Berati anticlinal belt and its subthrust, is linked to the compressive tectonic regime and resulting in overthrusting. This mechanism is valid not only for the carbonate reservoir, but also for most traps concerning the clastic reservoirs located in lithologicstratigraphic traps, formed during the Upper Miocene (e.g., the Kucova oil field, etc.) Many traps were completed when the Oligocene flysch was deposited on top of the carbonate. Hanging wall anticlines formed by high-angle faults are present beneath the overthrust of the Berati anticlinal belt.

Traps may also exist in the Lias shallow water carbonates sealed by Posidonia shales and the pelagic thin bedded Lower Cretaceous limestones.

Prospect in the Berati subthrust is associated with folded and faulted anticlines, which provide good structural traps, sourced by Mesozoic source rocks. These deep compressive structures are expected beneath the overthrust of the Berati anticlinal belt, forming the main objective of subthrust hydrocarbon accumulation in the Upper CretaceousEocene fractured carbonate. Hydrocarbon production from the carbonate depends on a system of faults and fractures.

The timing of oil generation and expulsion occurred in two phases: during the Lower Miocene and Pliocene. Migration on the carbonate interval occurred in simple pathways within a single thrust sheet, from mature source rocks at the depth, updip to reservoir in hanging wall anticline traps. All deposition within the Berati anticlinal belt shows the evidence of oil migration as in sample of wells drilled, as well as in surface seeps.

The Ionian Basin oil fields formed at different periods, depending on the trap-formation time and maturation stage of the source rocks, is reflected in oil composition changes. Condensate and light oil accumulations formed in the postPliocene (Carbonate oil fields: Cakran, Delvina and Shpiragu), whereas heavy oil accumulations formed earlier (Middle Miocene to Messinian) (Carbonate oil fields: Gorisht, Ballsh, Amonica, Karbunara, Visoka, etc., and clastic sandstones oil fields: Patos-Marinza, Kucova, etc.) (Curri 1993).

The clastic oil play comprises the Upper Miocene reservoir charged by Mesozoic deep-water carbonate rocks (Fig. 19), in lithologic-stratigraphic traps, formed above the unconformity (Fig. 19).

\section{Materials and methods}

For the geological interpretation of oil and gas exploration in the subthrusts of the Ionian zone in general, and the Berati anticlinal belt in particular, we used all the data available to date and my intensive experience and many studies on oil and gas exploration in these areas Velaj (1999; Aliaj 2004; Velaj 2011; etc.).

These data include regional geological studies on the tectonic style and development processes of the Ionian zone and of the Berati anticlinal belt in particular (Curri 1993; Velaj 2001; Karakitsios 2003; Zelilidis et al. 2003; Brita et al. 2006; Mavromatidis 2009; Vilas et al. 2009; AKBN 2012; Prifti and Muska 2010 etc.). We used the interpretation of the seismic data of modern works (3D) carried out in recent years by foreign companies (OMV, Petromanas Inc., Shell.com., etc.), together with the processing and reprocessing of $2 \mathrm{D}$ seismic data in combination with the results from deep wells (e.g., Shpiragu-1 5333 m, Shpirag-2 5800 m, Kanina-1 5312 m, Dumre-7 6119 m, Delvina 43550 m, Ardenica-7 6700 m, Fortuzaj etc.). This served as the basis of knowledge of the contemporary geology in depth and to explain the future subthrust exploration perspective (Aliaj 2004; Velaj 2011; Petromanas Energy Inc. 2013). In this paper, the structural stratigraphic and paleontological data were used from new studies of outcropping stratigraphic units and from deep wells drilling; Geochemical analysis was performed (Rock-Eval pyrolysis, bitumen isotope ratio, etc.) on oil and gas and oil-source rock correlation, together with optical analysis of selected kerogens (Curri 1993).

Analyzing all the data together, allowed us to make a contemporary interpretation of the depth geology and to give opinions on the exploration of the Albanian subthrust (mainly for the Berati anticlinal belt) and partially for the Greek territory (Ioannina area). 


\section{The tectonic development of the Berati anticlinal belt}

Tectonic evolution in the Berati thrust belt is mainly controlled by the relative movement of the Adriatic-Apulian subplate, which is located between the Eurasian and African plates, and dates from the Mesozoic to the Tertiary. During the rifting stage $\left(\mathrm{T}_{3}-\mathrm{J}_{3}-\mathrm{Cr}_{1}\right)$, the subplate moved in an ENE direction. It was then affected by extensional tectonics, and it formed a series of ridges and furrows, corresponding to present tectonic zones (Ionian, Kruja, Krasta, etc.) (Fig. 3) (Aliaj 2004; Velaj 2011). As a result of further movement in a SE direction during the collision stage $\left(\mathrm{Cr}_{2}\right.$-Serravallian), the tectonic style changed from extensional to compressional, which led to the folding of the Ionian zone and the development of the Berati, Kurveleshi and Cika anticlinal belts. Extensional faults created during the rifting stage were reactivated as thrusts, and the large-scale westward overthrust of the Berati anticlinal belt developed. The Triassic evaporites present the principal level of detachment.

During the postcollision stage (Serravallian- $\mathrm{N}^{2 \mathrm{P}}$ ), the front of the deformation migrated westward and a simultaneous westward emplacement of the Berati anticlinal belt occurred above the Memaliaj-Botsara synclinal belt (Figs. 12, 14, 15).

The main evolutionary features of the evaporite tectonic on the Berati belt were conditioned from the regional tectonic phenomena. It is evident that the thickness of the carbonate and flysch deposits increase from north to south and from west to east (Figs. 7, 8), creating an area of least thickness in the northeastern part (Glina-Zavrohon to Ioannina) thereby exerting the lightest pressure on the underplaced evaporite formation in this region (Fig. 7). Additionally, the flysch formation has a reduced thickness to the western edge of the Berati belt, which actually coincides with its regional tectonic fault (Figs. 5, 8). Consequently, the area from Glina-Zavrohon to Ioannina exerts the smallest lithostatic pressure on the evaporites, which enables intense development of the salt tectonics (Velaj 2001).

During the rifting stage $\left(\mathrm{T}_{3}-\mathrm{Cr}_{1}\right)$, the Berati anticlinal belt was divided into many horsts and grabens due to transverse and longitudinal listric faults (Fig. 14). During this stage (pillow stage), salt movement occurred due to buoyancy effects at the depressive and tectonically weak loops (Fig. 6), while in the compression stage $\left(\mathrm{Cr}_{2}\right.$-Serravalian) (diapir stage), the Berati anticlinal belt development, was a consequence of the joint action of tangential forces and the contribution of salt tectonics.

The influence of salt tectonics in determining the characteristics of the geology of the Berati anticlinal belt depends on a number of factors:
The lithostatic pressure applied to the evaporites varied at different positions, because of deposition thickness changes (Figs. 7, 8). In addition, in the early compression stage $\left(\mathrm{Cr}_{2}\right.$-Serravalian), longitudinal listric faults started to react by passing into thrusting faults. Thrust and overthrust took place during the compression stage $\left(\mathrm{Cr}_{2}\right.$-Serravalian $)$, in which the Berati anticlinal belt with all the elementary structures (anticlines, synclines etc.) more or less took its conclusive form (Figs. 6, 19). These faults originated during the rifting stage $\left(\mathrm{T}_{3}-\mathrm{J}_{3}-\mathrm{Cr}_{1}\right)$ and they were reactivated during the compression stage $\left(\mathrm{Cr}_{2}\right.$-Serravallian) (Velaj 2011).

The regional overthrust of the Berati anticlinal belt forms an arch (Figs. 9, 14). Its central part has a meridional direction (Molisht-Shpirag Zone), while both its extremities suffered deviations: The northern extremity shifted northeastward, while the southern extremity shifted southeastward. Therefore, this fault has western convexity with the presence on the surface of evaporite diapirs in its two extremities (Dumrea, Zavrohon) (Fig. 14).

The formation of the tectonic faults took place concurrently with the sedimentation and fold-formation processes. The fact that the Neogene Piggyback Basin $\left(\mathrm{N}_{1}^{3 \mathrm{t}}-\mathrm{N}_{2}^{\mathrm{P}}\right)$ of Kucova Bay is not touched by the overthrust tectonic of the Berati anticlinal belt (Fig. 19), shows that the tectonic activity ended before the Serravallian $\left(\mathrm{N}_{1}^{2 \mathrm{~S}}\right)$ (Velaj 2012).

The westward thrust process of the Berati anticlinal belt continued in the post-collision stage $\left(\mathrm{N}_{1}^{2 \mathrm{~S}}-\mathrm{N}_{2}^{\mathrm{P}}\right)$. This coincided with the inter formation of new fault planes (Fig. 8). As a result of this action, which continued with variable intensity throughout time, there were accompanying flysch deposits of folded subthrust complexes that "brought" in the western margin of the Berati thrust belt, exposed a rootless fold. Their root represents perspective structures in the subthrust (Figs. 10, 12, 15, 18) (Velaj 1999, 2012).

During this time, the evaporites were not in equilibrium, and they started to move along the thrust fault and tectonically depressive loops, causing the complication of the thrust and subthrust complexes. During the compression stage $\left(\mathrm{Cr}_{2}\right.$-Serravalian), the most favorable place for evaporite eruption was in the north part (Fig. 7). In most depressive loops, the eruption emerged on the surface (Figs. 9, 14), but in some places, they remained in the subsurface as "blind" diapirs (Fig. 14).

The frontal structures of the Berati anticlinal belt, in general, have bigger dimensions and a deeper erosional level which has conditioned a smaller lithostatic pressure on evaporites (Figs. 12, 16, 17, etc.). Therefore, the evaporites moved along the plane of the regional overthrust (Fig. 6) and helped the westward movement (Figs. 10, 12, $15,19)$. 


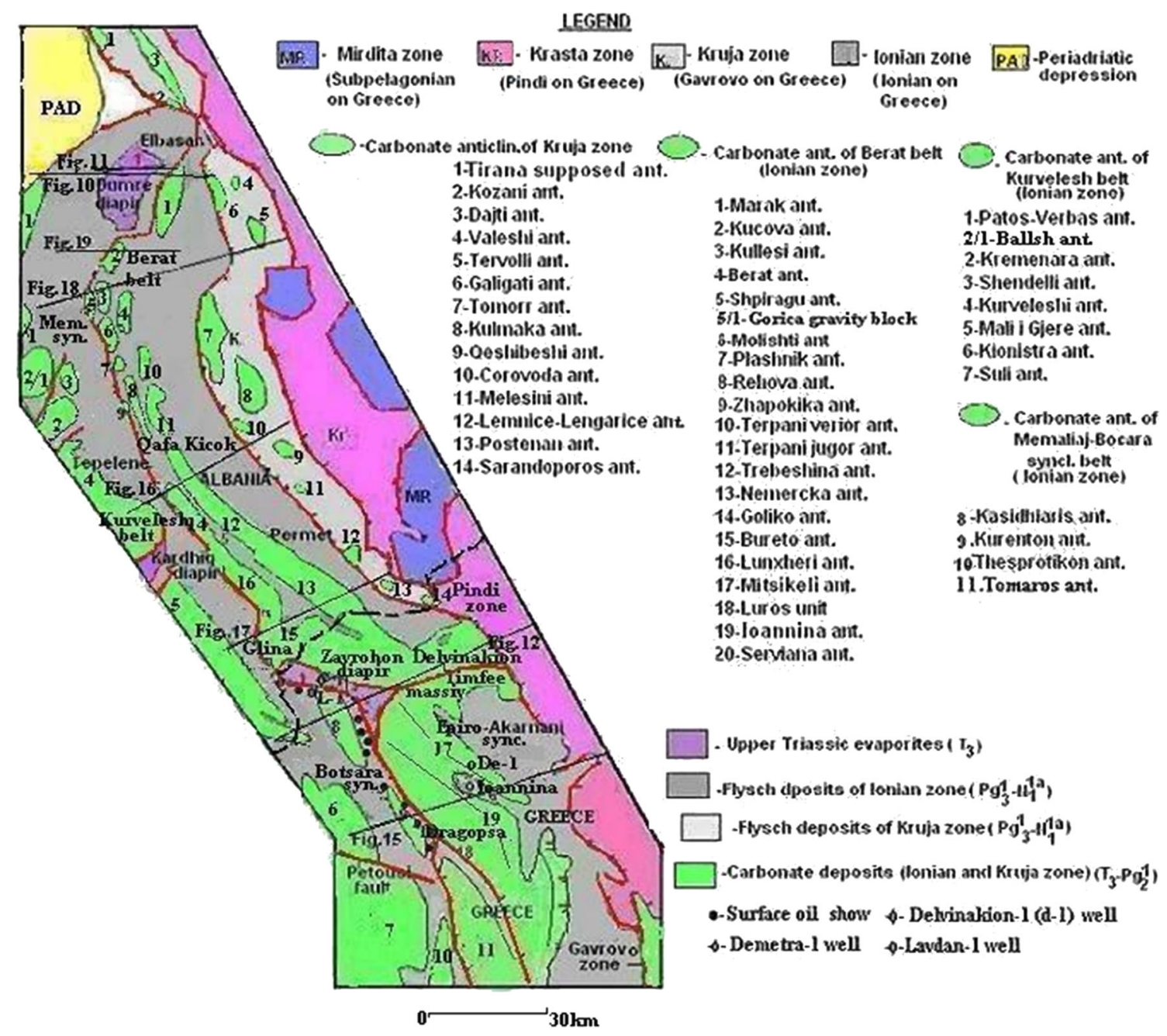

Fig. 14 The tectonic scheme of the Berati anticlinal belt and the areas around

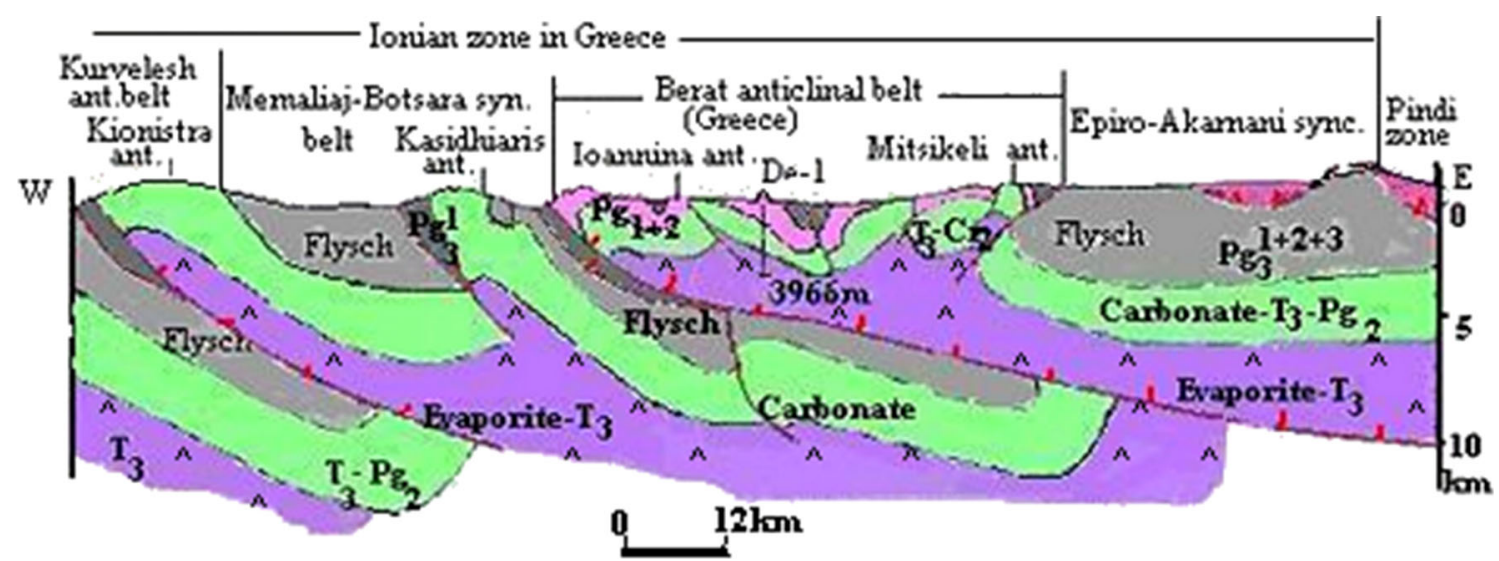

Fig. 15 The schematic geological cross-section in the Ioannina area, see Fig. 14 for location

We stress that, before and during orogeny (up to the Serravallian), the northern part of the Berati anticlinal belt was exposed on the surface, while its southern part plunged
(Fig. 13). These phenomena caused a total flow of evaporites from the south to the north. After orogeny, an inversion happened, which brought a change in the evaporite 


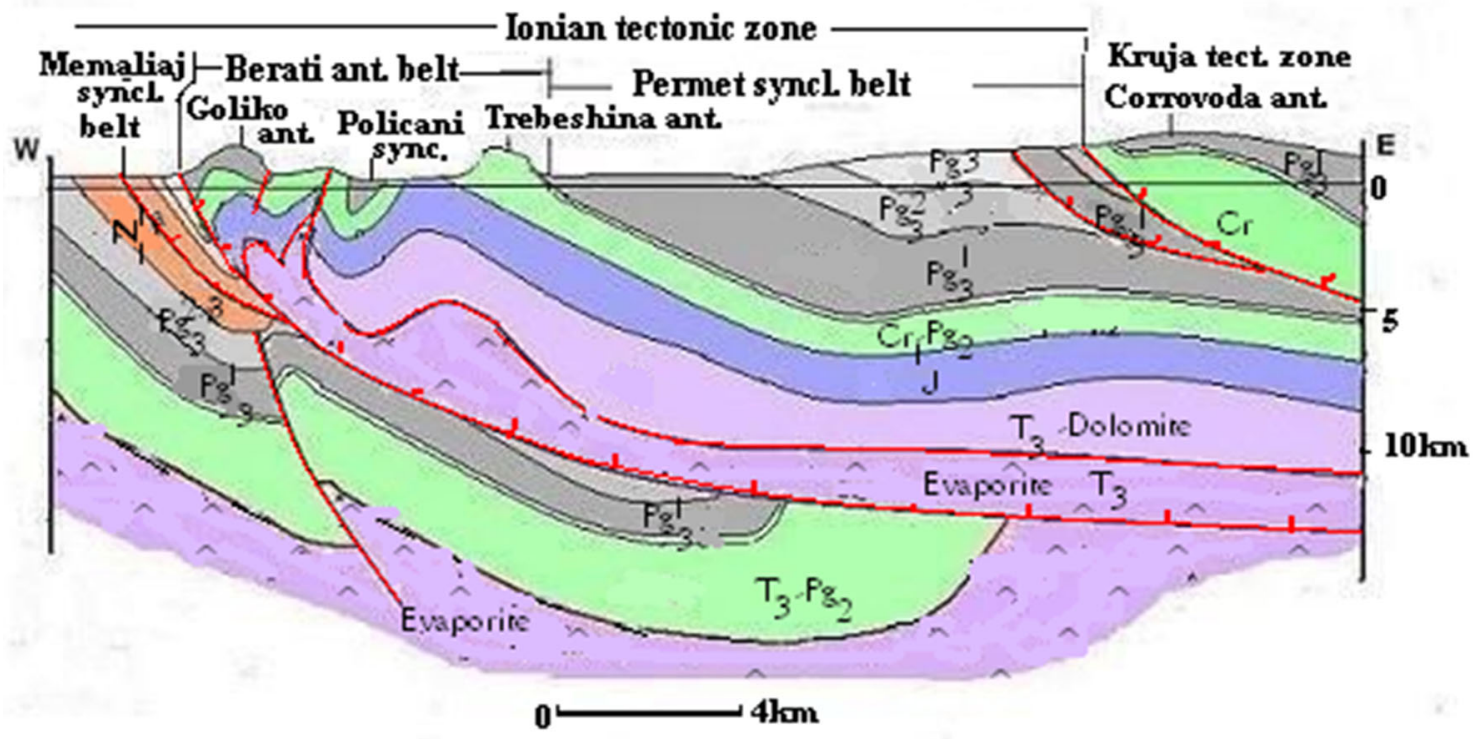

Fig. 16 The schematic geological cross-section in the Goliko area, see Fig. 14 for location

flow direction from the north to the south (Fig. 13). These phenomena further complicated the regional tectonics.

The evaporite eruptions related to the presence of weak tectonic nodules were conditioned from the intersection of the cross fault with longitudinal faults. Therefore, the Dumrea diapir was related to the intersection place of four regional tectonic faults: the Berati thrust belt fault, the strike-slip fault of the western edge of the Kurveleshi anticlinal belt, the strike-slip fault of the western edge of the Cika anticlinal belt, and the strike-slip fault of the western edge of the Kruja tectonic zone (Fig. 9). The Zavrohon diapir was related to the intersection of the Berati anticlinal belt strike-slip fault and that of Delvinakion (Fig. 14).

As a result of the joint action of all the presented factors, the most appropriate conditions for the eruption of evaporites were at the western edge of the Berati belt, because of the lower lithostatic pressures and the presence of the regional thrust fault, which had a suitable tectonic plane for evaporites flow because of their plasticity (Velaj 2001).

The high density of the evaporite body $\left(2.55 \mathrm{~kg} / \mathrm{m}^{3}\right)$ suggested that the buoyancy effect was non-existent at this time. However, a density inversion is not necessary to drive the evaporite diapir if there is a tectonic or differential loading mechanism. Moreover, the low viscosity of the halite matrix must have been crucial to allow the evaporites to move freely and produce diapirs (Velaj et al. 1998).

In this way, development of the evaporite tectonic depends on the deposition thickness (Figs. 6, 7) of the evaporite sedimentary cover and the presence of the tectonic depressive loops. These loops belong to the intersection of the transverse and longitudinal fault generated since the rifting phase ( $\mathrm{T} 3$ to $\mathrm{J} 3-\mathrm{Cr} 1$ ). In such intersection places, the Dumrea (Albania) and Zavrohon (Greece) diapirs erupted to the surface (Figs. 7, 12). The evaporites also extended along all of the regional overthrust faults of the Berati belt, and they helped increase the size of this overthrust (Figs. 10, 12, 17, 19).

\section{Diapiric structures}

\section{Dumrea diapir}

The Dumrea diapir is represented as a large old salt dome with a surface area of $210 \mathrm{~km}^{2}$ (the biggest evaporite body of the Albanides), which outcrops with an elliptical shape with axes $20 \times 10 \mathrm{~km}$. Its volume is about $2500 \mathrm{~km}^{3}$. The evaporite body has an ordinary diapiric shape with a thickness of about $6 \mathrm{~km}$ and a westward overthrust displacement of about 20-30 km (Fig. 10) (Velaj 2001; Roure et al. 2004).

A dense grid of seismic surveys was carried out in this area. There are plenty of seismic reflectors under the salt diapir body, recognized by the lack of reflectors. The base of the evaporite body, one strong seismic reflection, is recorded. The existence of many reflectors under the evaporite diapir, which extends west to east, shows that evaporites have come only from the east and northeast (Fig. 11). The seismic horizons under the salt body together with the data from the Dumre-7 well (in-depth $6110 \mathrm{~m}$ met Lower Oligocene deposits about $200 \mathrm{~m}$ away from the top of the carbonate), show the perspective of the carbonate subthrust for hydrocarbon exploration (Velaj 2001) Fig. 10). The new depth migrated lines, which offer better constraints on the 3D geometry of the structural closure, show that this structure extends to the northeast of the Dumre-7 well. The apex of the structure is now 
expected at a depth of about $5.5 \mathrm{~km}$ to the northwest of Dumre-7 (Jardin et al. 2011).

\section{Glina-Zavrohon diapir}

The surface appearance of the Zavrohon diapir is about $30 \mathrm{~km}$ long and $10 \mathrm{~km}$ wide. This diapir continues south under the Ioannina anticline up near Dragopsa (Figs. 14, 16). In this way, the length of the Zavrohon diapir is about $50 \mathrm{~km}$ and it causes the geological construction as a plateau of the anticline of Ioannina (Figs. 12,15) (Marnelis et al. 2007).

Because the intensity of evaporite tectonics is not the same everywhere, the effect on the space of the Berati thrust belt differs. Thus, in its southern part, as a result of a diapirism that has not emerged on the surface, it has aided in the development of positive fan-type structures of large dimensions (18-35 km long and 6-8 $\mathrm{km}$ wide), such as the Goliko, Nemercka and Mitsikeli (Greece) anticlines, with backthrusts in the eastern flank (Figs. 12, 14, etc.). In addition, the presence of a carbonate massive in the middle of the Epiro-Akarnani syncline (e.g. Timfeu massive, etc.) and the Ioannina anticline as a plateau (Figs. 12, 15, 16), is caused by the "blind" evaporite body effect (Karakitsios 2003). The Nemercka anticline goes directly to the south with the Mitsikeli anticline (Greece), with a length of about 80-90 km near the city of Arta (Fig. 14), having a total length of about $115-120 \mathrm{~km}$. This is one of the greatest mountains in the entire territory of the Ionian zone (Albania and Greece) (Karakitsios 2003).

The eruption time must be related to the early structuralism of the Berati anticlinal belt, and it has been also the affecting the east margin of the Memaliaj synclinal belt (Fig. 6).
The diapir eruption has been a continual process, starting from the extension (rifting) phase, and the maximal development it achieved during the compression stage. It took its last features in the post-collision stage, and during the first part of the compression stage (up to the Lower Oligocene). In the beginning, the evaporite tectonic is characterized by gravitational movements, while later, the orogenic movements predominated (Fig. 6).

\section{The geological setting of the Berati anticlinal belt}

The Berati thrust belt is situated on the most eastern side of the Ionian zone. It lies to the west of the Permet-Epiro-Akarnani syncline and to the east of the Memaliaj-Botsara syncline. It has the form of a mega anticline with trends of $310^{\circ}-180^{\circ}$. In general, the southern structures have the Albanides trend from the northeast to the southwest with an azimuth angle of $312^{\circ}$ (up to the Kelcyra Valley, Fig. 14), and further north, they suffer a deviation of an azimuth of $330^{\circ}$. This leads to the formation of a bounding in the Kelcyra site. This trend is also seen in the northern part of Shpiragu (Fig. 14), and further north, it suffers a deviation northeastward.

The structures of the Berati anticlinal belt are characterized by the anticline and syncline located on the tectonics lines, and these are placed in the form of steps towards one another (Fig. 14). In the southern part, the anticlinal line of Nemercka-Trebeshina-Terpani-Berati and the line of Bureto-Lunxheri-Goliko-Rehova are located in the east and in the west, respectively. These are separated by a narrow synclinal warp, which remains uncomplicated by any tectonic fault. The eastern structural line has the regular style, being represented by full structural elements, while the western structural line located on the front of it is

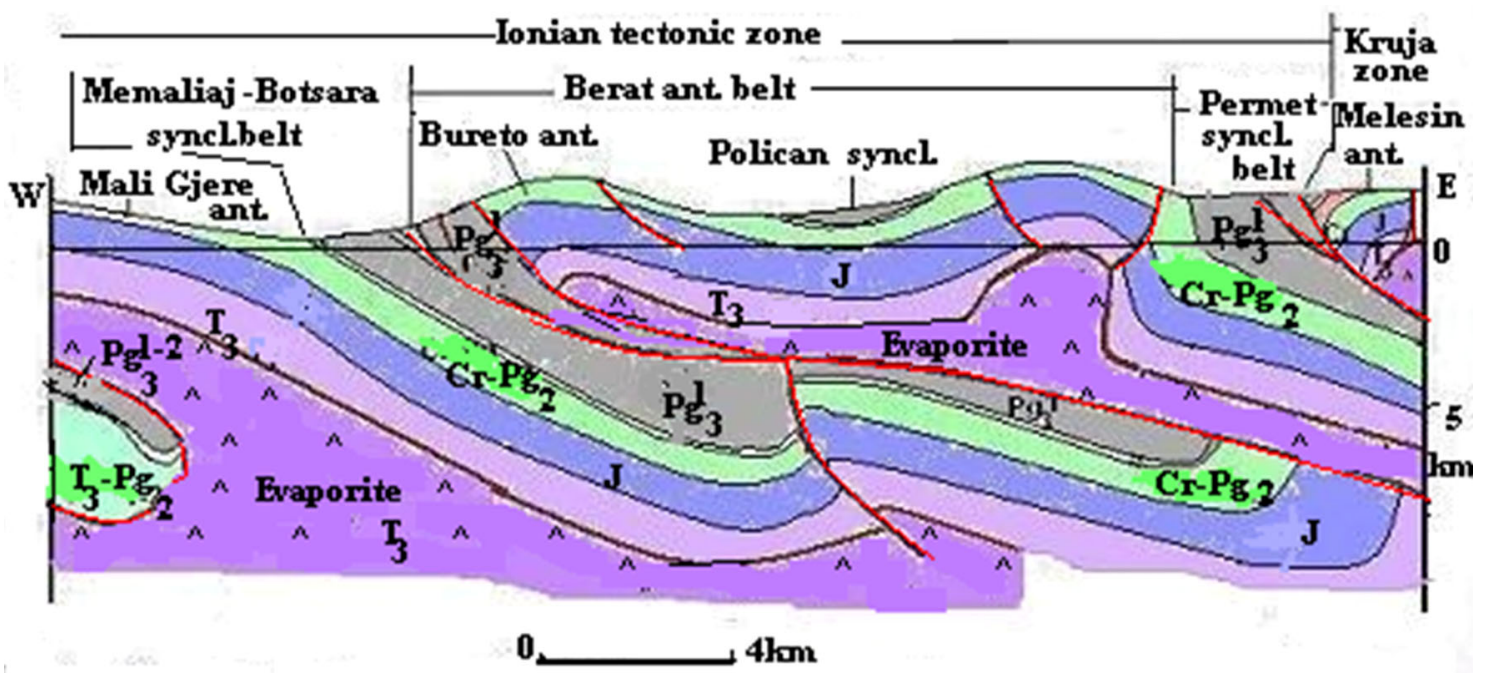

Fig. 17 The schematic geological cross-section in the Bureto area, see Fig. 14 for location 
more complicated, with the western side generally detached by thrust tectonic movements. These structural lines, within the larger anticlinal structures generally form the low-order structural elements, such as the structural nose, hunches, synclinal tongue, etc.

This anticlinal belt is characterized by a western asymmetry of anticline structures and some of them are in the form of the fan-type (Nemercka, Goliko and Mitsikeli). The anticlines of Goliko and Nemercka, in their southern parts, have an eastern asymmetry (Figs. 14, 16).

Development of the anticlinal structures throughout the eastern line (Nemercka-Berati line) (Fig. 14) continue along the entire belt, while the western line continues up to the Rehova anticline, where it melts within the synclinal and allows the development of other anticlinal lines in the northeast (Fig. 14). Thus, the Bureto anticline line ends at the Rehova anticline, but in the northwest, there is the anticline line of Gllava-Plashnik-Molisht-Kulles-Kucova, in which distinguished and other structures occur in the form of bumps as Zhapokika, Gllava and Plashnik.

More westerly, the Shpiragu anticline is developed, which forms the forehead of the most advanced part of the Berati anticlinal belt. Notice, that disconnecting and sliding towards the northwest from this anticline is the Gorica gravity block is of considerable size (Fig. 14) Velaj (1999).

The joint characteristic of the anticline structures of this anticlinal belt is their western asymmetry because of the westward thrusting. Sometimes, their western flank is missing on the surface, especially in structures of its most western line (Fig. 14).

As a result of orogenic action and evaporite movement, the Berati belt is differentiated in three sectors: (1) the sector southward of the Zavrohon diapir (Ioannina area), (2) the sector northward of the Zavrohon diapir (Zavrohon up to Qafa Kicoku) and, (3) the sector northward of the second sector (Qafa Kicoku up to the Dumre area).

The sector from the Zavrohon diapir to the south, which developed in the Greek territory, includes the following units: First, it includes the Mitsikeli anticline, which is the direct continuation of Nemercka anticline in the Albania territory (Fig. 14). This area has a very strong deformation, which is associated with an east-verged thrust fault (Mitsikeli backthrust), with an amplitude of $8-10 \mathrm{~km}$ and an overthrust in its west flank (Figs. 14, 15) (Karakitsios 2003, 2007). The Pogoniani monocline has a slight folding, and it is cut by several cross-tectonic faults, which end at the evaporite Zavrohon diapir (Figs. 12, 14, 15). The boundary between the Pogoniani monoclinal and northern structures is realized (Fig. 12) by an old cross-tectonic (the synsedimentary fault of the Delvinakion). Thanks to this cross fault and a "blind" diapir (Figs. 12, 14, 15), a carbonate massive developed (the Timfeu massive), which is in the center of the Epiro-Akarnani synclinal (continuity of the
Permeti synclinal). This synclinal's Cretaceous deposits are represented by dolomitic limestone, and it has a neritic facies in its eastern part (Karakitsios 2003; Marnelis et al. 2007).

The sector that developed from Zavrohon diapir up to Qafa Kicoku, has anticlinal structures with enormous dimensions, and it is represented by carbonate deposits $\left(\mathrm{J}_{3^{-}}\right.$ $\mathrm{Pg}_{2}$ ) which has in the core oldest deposists (the evaporites in the western flank of the Bureto anticline, Fig. 14), that are overthrust westward (Figs. 16, 17, etc.), rarely with a backthrust in the eastern flank (Nemercka and the Mitsikeli anticlines). The features of the backthrust on the eastern flank of the structures are very developed in the Greek territory, because of the diapir effect (Figs. 12, 15). This phenomenon is generally developed in the later phases of the collision stage $\left(\mathrm{Cr}_{2}-\mathrm{N}_{1}^{2 \mathrm{~s}}\right)$, due to the evaporite diapir tectonics and the reactive westward thrust process. In this sector (Fig. 14), two anticlinal structural lines developed: the Trebeshina and Nemercka anticlines in the east and the Goliko, Lunxheri and Bureto anticlines in the west. They are divided from one another by a narrow and shallow syncline, which is without any tectonic complication. The southern part of these structures has tectonic contact (in a synclinal tongue shape) with the evaporite diapir. Their anticlinal structures are very prolonged. The eastern line (Trebeshina, Nemercka and Mitsikeli anticline lines) continues northward with the Terpani and Berati anticlines, while the western one (Goliko, Lunxheri and Bureto anticline line) continue with only with Rehova anticline. The southern part of the Nemercka anticline (the biggest of the Berati belt) has a slight eastern asymmetry, and more to the south it passes into a fun shape, with an overturned backthrust in the east flank (Fig. 17), which is a result of an unsuccessful diapir. This anticline, near the Timfeu massive, is unified with the western line and is cut in two pieces from the Delvinakion cross fault (Fig. 14). The influence of the diapir is not noticeable in the Trebeshina anticline (Fig. 14), whose characteristics are similar to those we have seen throughout the Berati anticlinal belt. All the anticlines, mentioned above, are the brahi-anticlinal type. South to Qafa Kicoku (Fig. 14), an intrusive development of the evaporitic diapir is observed. The Zavrohon diapir, which is a surface diapir, is very intense in this sector, having developed a weak tectonic loop. This diapir is tectonically very complicated, which has influenced the structural model of the overlying deposits (Figs. 12, 14, 15). The structures of the western line (Bureto-Lunxheri-Goliko-Rehova) have western asymmetry and are limited by a regional fault that has an overthrust character (Figs. 14, 16, 17). To the south, the Bureto anticlinal has tectonic contact with the Zavrohon diapir and at the same time it appears in a specific view as a synclinal "tongue" and structural "nose" (Fig. 14). The Bureto anticline in its middle part has a monocline form, but 
Fig. 18 The schematic geological cross-section in the Shpiragu area, see Fig. 14 for location
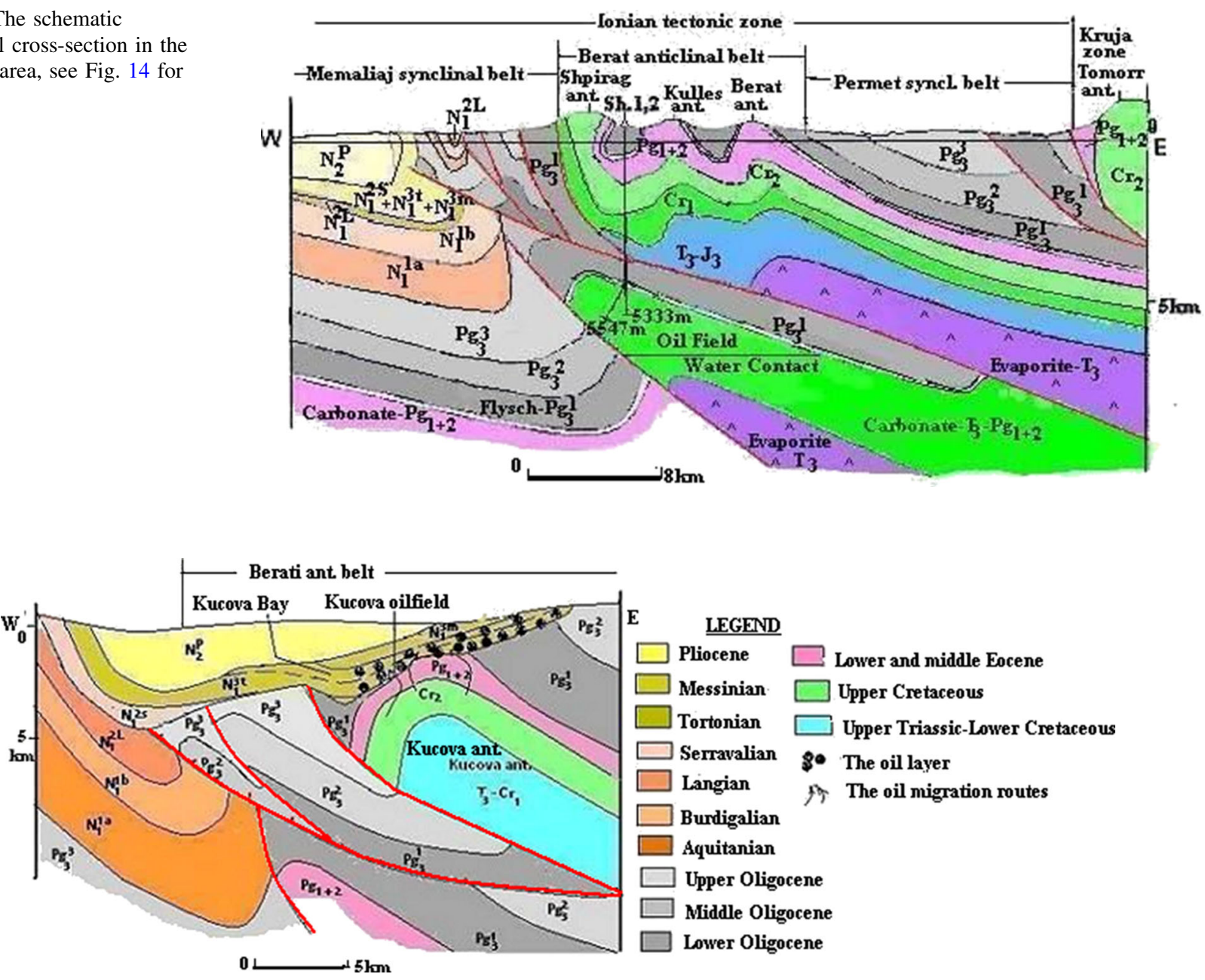

LEGEND

Pliocene

Messinian

Tortonian

Serravalian

Langian

Burdigalian

Aquitanian

Upper Oligocene

Middle Oligocene

Lower Oligocene

Fig. 19 The schematic geological cross-section in Kucova Oilfield, see Fig. 14 for location

to the north and south, it changes into the structural "nose" form (Fig. 14). The southern part has tectonic contact (in a synclinal tongue shape) with the Zavrohon diapir. The evaporites of Glina, which meet in the tectonic fault of the western flank of the Bureto anticline, are on the continuity of the Zavrohon diapir, which has helped the amplitude of the regional overthrust of the Berati anticlinal belt. Northward, the fault of the western flank of the Lunxheri anticline continues to the eastern flank of the Goliko anticline (Fig. 16) that looks like a horst under the influence of the unsuccessful diapir (Fig. 16). The anticline of Goliko has a fan-shape and development morphology. In this anticline, secondary structures are found. Besides the above characteristic, in the structures distinguished set up of them as "steps". In addition, we see the existence of secondary folds in "nose" shape and with tectonic complications (Fig. 14).

In the northern sector of the Berati anticlinal belt (from Qafa Kicoku up to Dumrea), the dimensions of the structures are smaller than those of the southern part, and the amplitude between them is about $1500-2000 \mathrm{~m}$ (Fig. 14). This total lift of the southern part of the Berati anticlinal belt compared to the northern part, shows the intensive development of the evaporite tectonic in that area (Figs. 12, 15, 17). The two most eastern structural lines (Terpani-Berat and Rehova) are direct continuations of the southern one (Fig. 14). Northwestward, some of the structural lines appeared, with the view of the cupola form (Zhapokika and Plashniku anticlines) and others with the brahiantclinal shape. The structural dimensions here are smaller in comparison to the southern ones, but their density at the surface is higher. The structural axes are gradually plunged northward. The separating syncline of the anticline lines is generally shallow and continuous. The Kulles and Zhapokika anticlines are tectonically restricted northward in their two flanks (Fig. 14) forming a "horst" model. The Marak anticline is represented by a dozen transverse faults in its northern part, due to the Dumrea evaporite diapirs (Fig. 14) (Velaj 2001). 
Fig. 20 The schematic tectonic map of perspective plays in subthrust of the Berati thrust belt

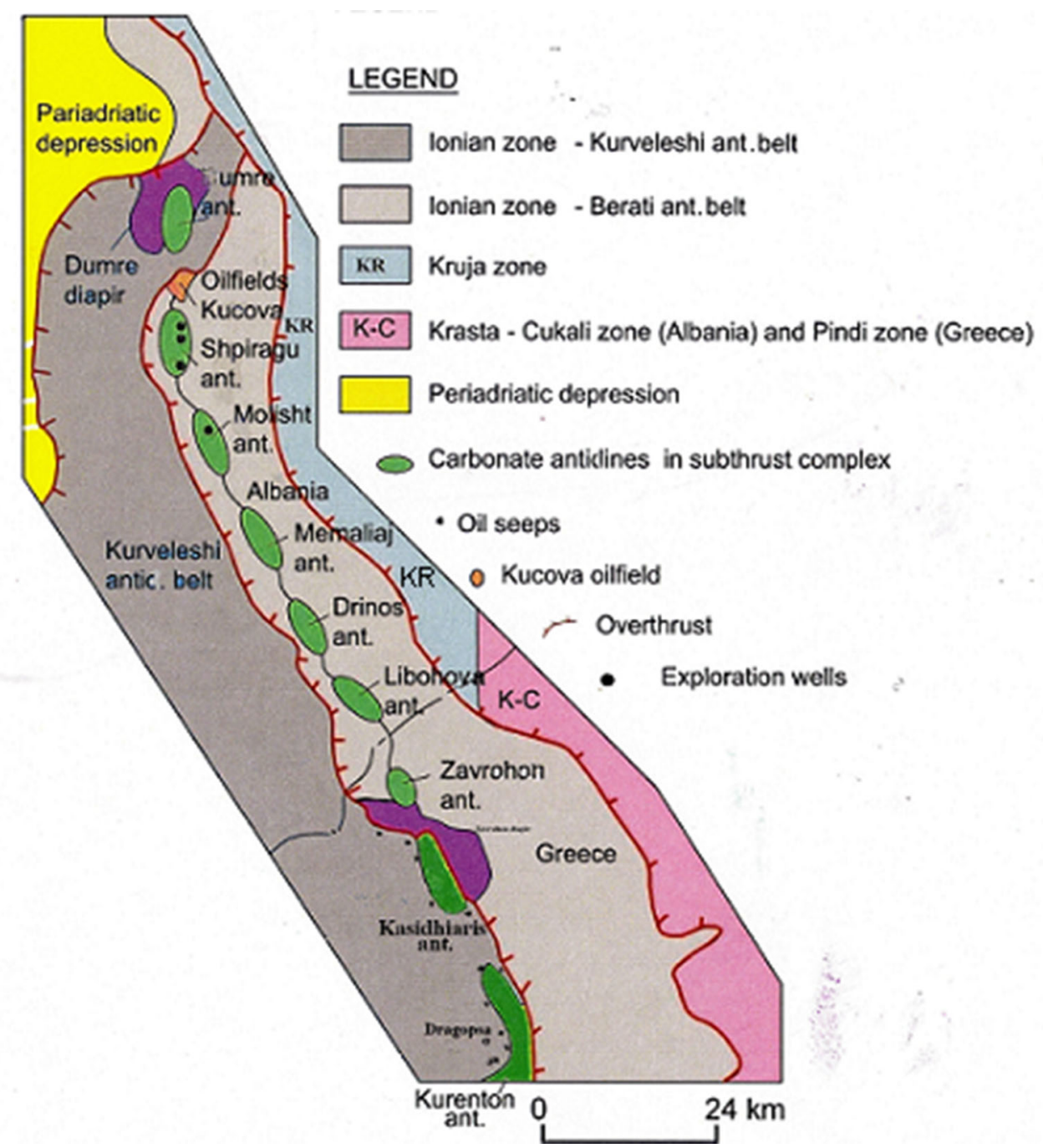

Geological-geophysical studies have predicted in the subthrusts, the Dumrea and Shpiragu carbonate anticlines (Figs. 10, 11, 18), which underlie the Berati anticlinal belt (Velaj 2011).

Outcrops data in the Greek territory (Fig. 14) show an anticline structural line, in the west of the regional fault of the Berati belt (Thesprotikon, Kurenton and Kasidhiaris anticlines) and in the eastern margin of the Botsara syncline. This line continues northward under the Zavrohon diapir (Figs. 12, 14, 15) and further north under the overthrust of the Berati anticlinal belt in Albania (Fig. 20) Velaj (1999).

\section{Petroleum potential of the Berati anticlinal belt}

Surface oil seeps in the Berati anticlinal belt (Kucova, Rehova, Plashnik, etc.) have been observed since the beginning of the last century (1926) and they have drawn the attention of many scientists for further exploration.
After a few years, in Kucova, drilling focused around the area of the surface seepage started, leading to the discovery of bitumen impregnation. This led to the discovery of the first oil field in Albania (1928), within the TortonianUpper Miocene sandstones. These deposits overlie the thrust anticline of eroded carbonate (Fig. 19).

The oil field consists of multiple stacked sand and sandstone reservoirs. The oil migrates from carbonate reservoirs (Fig. 19). Up to now, the cumulative production from this oil field has been around 24 million barrels.

In Greece, surface oil seeps have been found mostly along the eastern margins of the Botscara syncline (Fig. 14) from Dragopsa to the Zavrohon diapir, in the contact tectonic thrust fault between the carbonate and overlying units (Karakitsios 2003). They are observed mainly in the west flank of the Ioannina anticline and in the eastern flanks of the Kasidhiaris, Kurenton and Thesprotikon anticlines (Fig. 14) (Mavromatidis et al. 2004; Mavromatidis 2009). Exploration activity in the Dragopsa 
area began in 1919. Some of the wells that were drilled in this area have in-depth provided evidence of a small amount of oil (Lavdani-2, Delvinakion-1, etc.).

Potential new reserves of oil and gas in Albania will be found in three main objects (Velaj 2011):

First, they will be found in the subthrust plays in the overthrust belt (Berati, Kurveleshi and Cika anticlinal belts), which have masked the folded anticlinal structures (Shpiragu oil field, Dumre anticline, etc.) (Fig. 20). These structures represent the duplex style.

Second, they will be found under the overthrust of the tectonic zones (Ionian and Kruja Zones) above the western autochthonous formation (Apulia and South Adriatic Basin), which has masked the structures with large dimensions and high perspective. These structures represent the duplex and triplex styles.

Third, they will be found under the overthrust of the anticline units, which have mostly developed in the Kurveleshi anticlinal belt. Its magnitude is $5-10 \mathrm{~km}$. These overthrusts formed imbrications and duplex structures style, masking the subthrust complex with structures of great interest, as in Delvina and Kremenara (buried duplex) (Fig. 5) (Velaj et al. 1999; Velaj 2011).

The Berati anticlinal belt overthrusts westward with an amplitude of $20-30 \mathrm{~km}$ and masks the subthrust complex, underneath where some very perspective plays for oil and gas exploration have developed. From the north to the south, these structures are as follows: Dumrea anticlinal (Fig. 10), Shpiragu oil field anticline (Fig. 18), Molishti anticline (Fig. 20), Drinos anticline (Fig. 16), Libohova anticline (Fig. 17) and Zavrohon anticline (Fig. 12) Velaj (1999).

All these structures are set up in the structural line with the Kasidhiaris, Kurenton, Thesprotikon anticlines in the Greek territory (Figs. 14, 20). The primary exploration targets the fractured carbonate reservoirs. These deposits are highly fractured due to the tectonic processes.

The Triassic and Jurassic organic shales are the main source rock for oil generation. They have good to excellent quality (Prifti and Muska 2010) and they attained the largest distribution, in the Peri Aadriatic region, during the middle Triassic to early Jurassic (Zappaterra 1994).

Traps in the subthrust carbonate are hanging wall anticlines with three and four-way closure.

In the Dumre region, the data of the Dumre-7 well (6119 $\mathrm{m}$. depth, around $200 \mathrm{~m}$ from the top of the carbonate) and the seismic data (Fig. 10) show that under the evaporite sheet, one big anticlinal structure developed with a very high perspective for oil and gas exploration. The area size of structures is $60 \mathrm{~km}^{2}$. The top of the carbonate is around $6400 \mathrm{~m}$ (Figs. 10,11), and further northeast of Dumre-7, it is around $5.5 \mathrm{~km}$ (Jardin et al. 2011).
In December 2001, Occidental Petroleum's Shpiragu-1 well, flowed light oil to the surface from one anticlinal structure with the three-way closure, in the subthrust complex under the overthrust of the Berati anticlinal belt (Fig. 18). This well reached a total depth of $5333 \mathrm{~m}$ (top of the carbonate $4930 \mathrm{~m})$ and tested light oil $\left(37^{\circ} \mathrm{API}\right)$ with a rate of about $340 \mathrm{bbl} / \mathrm{d}$. The maximum closure was around $60 \mathrm{~km}^{2}$ and the oil column was $400 \mathrm{~m}$. The oil-water contact was much higher than $400 \mathrm{~m}$ (perhaps closer to $1200 \mathrm{~m}$ ). The second well Shpiragu-2, is now in action. This well has reached the top of the carbonate at $4750 \mathrm{~m}$ (180 m higher than Shpiragu-1). The total depth of this well will be around $5800 \mathrm{~m}$. The last statement for this well shows that it reached a total depth of $5600 \mathrm{~m}$ and will be tested in November 2013 (Petromanas Energy Inc. 2013). On November 04, 2013, Petromanas Energy and its joint venture partner Royal Dutch Shell, announced the discovery of the light oil at Shpiragu-2, with a flow rate of 800-1300 barrels per day in 35-37 degree API, and 2-5 Mmcfd gas (Fig. 18). These companies believe that they have an $800 \mathrm{~m}$ oil column in fractured carbonate reservoirs at the Shpiragu structure, but they were able to test only $400 \mathrm{~m}$, due to drilling setbacks. These test results confirm the well's ability to flow light oil and they validate of the potential of the subthrust structures of the Berati anticlinal belt. Petromanas and Shell are continuing to drill the Molishti prospect, $18 \mathrm{~km}$ to the southeast of Shpiragu-2 (Fig. 20). This well is currently at a depth of $4600 \mathrm{~m}$ on its way to a targeted $5500 \mathrm{~m}$ so that data can be collected and well tested. This well reached the top of the Molishti anticline, under the overthrust of the Berati anticlinal belt, at a depth $4174 \mathrm{~m}$ (around $300 \mathrm{~m}$ higher than the originally project and around $600 \mathrm{~m}$ higher than Shpiragu-2). The well was cemented at this depth $3274 \mathrm{~m}$, leaving roughly $900 \mathrm{~m}$ unstable flysh (3274-4174 m) behind the pipe before drilling ahead. All the structures southward (Figs. 12, 18, etc.), up to the Kasidhiaris anticline (Greece), have a high perspective for exploration for oil and gas with the same characteristics as the Shpiragu oil field. The traps beneath the main detachment level of the overthrust of the Berati anticlinal belt will be the main target of future exploration. The reservoir rocks are in the Upper CretaceousEocene $(\mathrm{Cr} 2-\mathrm{Pg} 2)$ formations, generally with low matrix porosity and with the massive detrital limestone, which sometimes have good porosity of up to $8 \%$. The Oligocene flysch is the seal for hydrocarbon accumulation in subthrust carbonates (Karakitsios 2003).

Evaluation of geological and geophysical data led to the determination of the Ioannina prospect under the Zavrohon diapir sheet. The Demetra-1 well was projected for this object in 2001. The ambitious target was to penetrate the Triassic evaporite sequence for the first time. Seismic interpretation showed the existence of a salt dome at a depth 
of $4000 \mathrm{~m}$. Following penetration of the Ioannina carbonate sequence $(0-1897 \mathrm{~m})$ and while still within the evaporites (1897-3966 m), the drilling met exceedingly high pressure. That prohibited the continuation of drilling. That led to the plugging and abandonment of the well. Therefore, the initial aim was not achieved. It is possible under the overthrust of evaporites to develop a carbonate perspective structure (Fig. 12), such as the southern continuation of the Tomaros anticline (Marnelis et al. 2007). This anticline develops in the west of the Ioannina anticline and it should continue northward under the overthrust (Figs. 14, 15). In this way, it is possible to develop an oilbearing carbonate structure under the Ioannina anticline, which may have been the cause of the high pressure in the Demetra-1 well. This anticline should continue under the overthrust of the Zavrohon diapir (Fig. 12) and perhaps even further north in the Albanian territory.

\section{Conclusions}

Based on the analysis of all the data, we reach the following conclusions:

Western Albanian geology (External Albanides) is dominated by a series of NNW-SSE structural thrust sheets divided into tectonic zones. The zones from west to east are as follows: the Sazani (pre-Apulian), Ionian, Kruja and Krasta-Cukali. The Ionian Zone is subdivided into three anticlinal belts from east to west: The Berati, the Kurveleshi and the Cika anticlinal belts.

The Berati anticlinal belt is the most eastern in the Ionian zone and it is spread partly in Albanian and in Greek territory and overthrust considerably towards the west (20-30 km), thereby hiding perspective structures that occur in the subthrust. Presently, the joint venture of Shell and Petromanas (with Shell at a $75 \%$ share) is performing intensive drilling activity (Shpiragu-2 (current) and Shpiragu3, Shpiragu-4 and Molishti-1)(scheduled) (Fig. 8), and seismic works, to discover the oil fields in the subthrust.

The evolution of evaporite tectonics is very important in the determination of the principal features of the structural model in the Berati anticlinal belt. The diapir eruption has been a continuous process, starting from the rifting stage $\left(\mathrm{T}_{3}\right.$ to $\mathrm{J}_{3}-\mathrm{Cr}_{1}$ ), with its maximal development achieved during the compression stage $\left(\mathrm{Cr}_{2}\right.$-Serravallian). Its final features were created in the post-collision stage (Serravallian to Pliocene). In the beginning, the evaporite tectonics was characterized by gravitational movements; later, the orogenic movements dominated.

There are two types of hydrocarbon accumulation in Albania: fractured limestones of Upper Cretaceous-Eocene carbonate of the Ionian zone and those in the Neogene of the Peri-Adriatic Depression.
The oil fields in carbonate are of two types: (1) thrust oil fields (Amonica, Ballshi, Cakrani, Gorisht-Koculi, FiniqKrane, Hekal, Gernec and Visoka; and (2) subthrust oil fields (Delvina, Karbunara and Shpiragu).

To date, there has been limited exploration of the subthrust. The advances in three-dimensional technology and deep drilling have created possibilities for the exploration of the Albania subthrust.

The oil fields in the Messinian-Tortonian are as follows: Patos-Marinza, Kucova, Pekisht-Murrizi.and Bubullima.

The gas fields are: (1) In the Messinian-Tortonian: Divjaka, Frakulla, Povelca, Panaja, Durresi; (2) In the Pliocene (Ballaj, Divjaka).

The complexity and diversity of the subthrust plays remain a challenge to future exploration for oil and gas in Albania. At present, the more interesting play is the subthrust beneath the overthrust of the Berati anticlinal belt, which has already experienced intensive activity (drilling and seismic works) from the Shell and Petromanas companies. At same time, the subthrust beneath the overthrust of the other anticlinal belts (Kurveleshi and Cika) and beneath the overthrust of the External Albanides (Ionian and Kruja Zones) (Fig. 5) are the main object of interest for the immediate future.

Acknowledgments The structure and evolution of the External Albanides in general, and particularly the Berati anticlinal belt, has been the subject of numerous scientific studies conducted by Albanian geologists, as well as foreign authors. I thank all the authors (Prof. Alfred Frasheri, Prof. Shyqyri Aliaj and Karatiksios V., etc.), who helped me. These works, together with my long experience in oil and gas exploration in the Albanian territory, have led to a very large perspective for research on subthrusts. In addition, I thank Petromanas Energy Inc. for their serious work done in oil and gas exploration in the Berati anticlinal belt and for their publication of all the data with full transparency.

Open Access This article is distributed under the terms of the Creative Commons Attribution License which permits any use, distribution, and reproduction in any medium, provided the original author(s) and the source are credited.

\section{References}

AKBN (National Agency of Natural Resources) (2012) Petroleum exploration opportunities in Albania, Beograd, 2009

Aliaj SH (2004) The Albania orogen: Convergence zone between Eurasia and the Adria microplate. The Adria Microplate: GPS geodesy, tectonics and hazards. 2006 Springer. Printed in the Netherlands. pp 133-149

Argnan A (2010) Variations in structural style along the front of the Albanides fold belt and heritage of Mesozoic paleogeography. ILP Task Force on sedimentary basins. November 7-12 2010, Tirana (Albania)

Bega Z (2010) Platform carbonate subthrusts as major hydrocarbon plays in NW Albania-Montenegro region. ILP Task Force on Sedimentary Basins. In: International workshop. November 7-12, Tirana, Albania, pp 27-30 
Brita R, Wall R, Girbacea R et al (2006) Evolution of fracture and fault-controlled fluid pathways in carbonate of the Albanides fold-thrust belt. AAPG Bull 90(8):1227-1249

Cazzola A, Fantoni R, Franciozi R. et al (2011) From thrust and fold belt to foreland basins: hydrocarbon exploration in Italy. Search and discovery, Article \#10374 (2011)

Curri F (1993) Oil generation and accumulation in the Albanide Ionian Basin. Spec Publ Eur Assoc Pet Geol 3:281-293

Frasheri A, Salvadori B, Bare V (2009) Geophysical outlook on structure of the Albanides. J Balk Geophys Soc 12:9-30

Heard G, Robinson M (2010) Acreage in the Southern Adriatic and future exploration potential. In: 8th Maghreb and Mediterranean Conference in Mavrakesh, Maroco. November, 2010

Jardin A, Roure F, Nikolla L (2011) Subsalt depth seismic imaging and structural interpretation in Dumrea area, Albania. Oil and gas science Technology, Rev. IFP. Energie nouvelles, vol 66, no 6, pp 919-929

Karakitsios V (2003) Evolution and petroleum potential of the Ionian Basin (Northeast Greece). In: AAPG international conference and exhibition, September 21-24, 2003, Barcelona, Spain

Karakitsios Rigakis N (2007) Evolution and petroleum potential of Western Greece. J Pet Geol 30:197-218

Marnelis F, Roussos N, Rigakis N, Karakitsis V (2007) Structural geology of the Western Greece. Planning for the Greek Licencing round, Nicosia, January 26, 2012

Mavromatidis A (2009) Review of hydrocarbon prosectivity in the Ionian basin, Western Greece. Energy Sour Part A 31:619-632

Mavromatidis A, Kelessidias VC, Monopolis DG (2004) A review of recent hydrocarbon expploration in Greece and its pontetial. In: 1st international conferenceon advances in minerals resource management and envirnmental geotechnology, 7-9 June 2004, Chania, Crete, Greece

Meco S, Aliaj SH (2000) Geology of Albania. Publisher: Gebruder Borntraeger, 246 pages, 116 figs, 1 tab

Petromanas Energy Inc. (2012) Sepac-investor showcase, November 21, 2012

Petromanas Energy Inc (2013) Corporate presentation 2013

Picha F (1998) Exploration for hydrocarbons under thrust Belts-A challenging frontier. AAPG search and discovery article \# 90937. AAPG Annual convention and exhibition, Salt Lake, Utah

Picha F (2002) Late orogenic strike-slip faulting and escape tectonic in frontal Dinarides-Hellenides. Croatia, Yugoslavia, Albania and Greece. AAPG Bulletin 86(9):1659-1671
Picha F (2011) Late orogenic faulting of the foreland plate: an important component of petroleum system in the orogenic belts and their forelands. AAPG Bulletin 95:957-981

Prifti I, Muska K 2010) Hydrocarbon occurrences and petroleum geochemistry of Albania oils. International workshop, November 7-12, Tirana, Albania, p 137-143

Roure F, Nazaj SH et al (2004) Kinematic evolution and petroleum system- An appraisal of the outer Albanides in K. R. McClays, thrust tectonics and hydrocarbons systems. AAPG Mem. $82: 474-493$

Scrooca D (2010) Southern Apennines: Structural setting and tectonic evolution. J Virtual Explor, Electronic Edition, ISSN 1441-8142, vol 36, paper 13

Velaj T (1999) Exploration in overthrusting tectonic zones. In: 2nd international symposium on petroleum geology. April 22-24, 1999. Zagreb, Croatia pp 79-84

Velaj T (1999) The effect of the evaporite tectonic in the structural model of the Berati belt of Albanides. In: Second Balkan geophysical congress and exhibition. Istanbul, July 5-9, pp 184-185

Velaj T (2001) Evaporite in Albania and their impact on the thrusting processes. Journal of the Balkan Society, vol 4, no 1, February 2001, pp 9-18

Velaj T (2011) Tectonic style in Western Albania Thrustbelt and its implication on hydrocarbon exploration. AAPG search and discovery Article \#10371. November 2011

Velaj T (2012) Tectonic style and hydrocarbon exploration evaluation of duplex Kruja zone in Albania. Nafta J Nr. 63, no 7-8, Zagreb, Croatia, pp 236-242

Velaj T, Jano K, Gjani E (1998) Salt movement on external Albanides and its implications for thrust and subthrust complex. In: EAGE conference and technical exhibition, Leipzig, Germany, 8-12 June, 1998, p 533

Velaj T, Davison I, Serjani A (1999) Alsop I (1999) Thrust tectonic and the role of evaporites in the Ionian zone of the Albanides. AAPG Bull 83(9):1408-1425

Vilas N, Malandain J, Barrier L et al (2009) From outcrop and petrographic studies to basin-scale fluid flow modelling: The use of the Albanian natural laboratory reservoir characterization. Tectonophysics pp 367-392

Zappaterra E (1994) Source-rock distribution model of Periadriatic Region. AAPG Bull 78:394-421

Zelilidis A, Piper DJ, Vakalas I, Avramidis P, Getsos (2003) Oil and gas plays in Albania: do equivalent plays exist in Greece? J Pet Geol 26(1):29-48 